\title{
Genetic rescue of $\mathrm{CB}_{1}$ receptors on medium spiny neurons prevents loss of excitatory striatal synapses but not motor impairment in HD mice
}

\author{
Alipi V. Naydenov ${ }^{1,2}$, Marja D. Sepers ${ }^{3}$, Katie Swinney ${ }^{4}$, Lynn A. Raymond ${ }^{3}$, Richard \\ Palmiter ${ }^{5}$, and Nephi Stella ${ }^{4}$ \\ ${ }^{1}$ Medical Scientist Training Program, University of Washington, Seattle WA USA \\ ${ }^{2}$ Graduate Program in Neurobiology and Behavior, University of Washington, Seattle WA USA \\ ${ }^{3}$ Department of Psychiatry, Brain Research Centre, University of British Columbia, Vancouver, \\ BC, Canada \\ ${ }^{4}$ Department of Pharmacology, University of Washington, Seattle WA USA \\ ${ }^{5}$ Howard Hughes Medical Institute, Department of Biochemistry, University of Washington, \\ Seattle WA USA
}

\section{Abstract}

\begin{abstract}
Huntington's disease (HD) is caused by an expanded polyglutamine repeat in huntingtin protein that disrupts synaptic function in specific neuronal populations and results in characteristic motor, cognitive and affective deficits. Histopathological hallmarks observed in both HD patients and genetic mouse models include the reduced expression of synaptic proteins, reduced medium spiny neuron (MSN) dendritic spine density and decreased frequency of spontaneous excitatory postsynaptic currents (sEPSCs). Early down-regulation of cannabinoid $\mathrm{CB}_{1}$ receptor expression on MSN $\left(\mathrm{CB}_{1(\mathrm{MSN})}\right)$ is thought to participate in HD pathogenesis. Here we present a cell-specific genetic rescue of $\mathrm{CB}_{1(\mathrm{MSN})}$ in $\mathrm{R} 6 / 2$ mice and report that treatment prevents the reduction of excitatory synaptic markers in the striatum (synaptophysin, vGLUT1 and vGLUT2), of dendritic spine density on MSNs and of sEPSCs, but does not prevent motor impairment. We conclude that loss of excitatory striatal synapses in $\mathrm{HD}$ mice is controlled by $\mathrm{CB}_{1(\mathrm{MSN})}$ and can be uncoupled from the motor phenotype.
\end{abstract}

() 2014 Elsevier Inc. All rights reserved.

Corresponding Author: Dr. Nephi Stella, nstella@uw.edu, 1959 N.E. Pacific St., BB1538 HSB, Seattle, Washington, 98195. (phone) 206-221-5220 (fax) 206-543-9520.

Publisher's Disclaimer: This is a PDF file of an unedited manuscript that has been accepted for publication. As a service to our customers we are providing this early version of the manuscript. The manuscript will undergo copyediting, typesetting, and review of the resulting proof before it is published in its final citable form. Please note that during the production process errors may be discovered which could affect the content, and all legal disclaimers that apply to the journal pertain.

CONFLICTS OF INTEREST:

The authors declare no competing financial interests. 


\section{INTRODUCTION}

The early down-regulation of $\mathrm{CB}_{1}$ (MSN) was first observed in post-mortem tissue of $\mathrm{HD}$ patients and occurs in most mouse models of HD, including R6/2, R6/1, YAC128 and HdhQ150 mice (Dowie et al., 2009; Glass et al., 2000; Pouladi et al., 2012; Woodman et al., 2007). It was recently reported that mutant huntingtin acts at the Cnrl promoter and inhibits $\mathrm{CB}_{1}$ expression in neurons (Blázquez et al., 2010). Down-regulation of $\mathrm{CB}_{1(\mathrm{MSN})}$ - the neuronal population expressing the highest amount of $\mathrm{CB}_{1}$ receptors (Herkenham et al., 1990) - precedes the loss of other synaptic proteins, including dopamine D2 and D1 receptors and striatal synaptophysin (Glass et al., 2000). Furthermore, it is known that functional $\mathrm{CB}_{1}$ receptor signaling allows neurons to better resist various insults and pathological events by, for example, reducing excitotoxicity and regulating growth factor expression (Katona and Freund, 2008). Together, this evidence led to the hypothesis that $\mathrm{CB}_{1(\mathrm{MSN})}$ dysfunction controls downstream pathological events occurring in HD patients and mouse models (Maccarrone et al., 2007). For example, the genetic deletion of $\mathrm{CB}_{1}$ receptors in HD mice models both accelerates the motor phenotype and aggravates HD pathogenesis measured in the striatum, suggesting that $\mathrm{CB}_{1}$ signaling might participate through an unknown mechanism in the development of HD (Blázquez et al., 2010; Mievis et al., 2011). In line with this result, environmental enrichment both improves the phenotype of $\mathrm{HD}$ mice models and increases $\mathrm{CB}_{1}$ receptor expression in MSNs, without rescuing the expression of other proteins (D1, D2, and $\mathrm{GABA}_{\mathrm{A}}$ receptors) (Glass et al., 2004). Nevertheless, other groups have suggested that $\mathrm{CB}_{1}$ loss in $\mathrm{HD}$ may in fact be a compensatory event that corrects impaired D2 receptor signaling (Eidelberg and Surmeier, 2011).

Several attempts to increase $\mathrm{CB}_{1}$ signaling by pharmacological treatment in $\mathrm{HD}$ mouse models led to divergent conclusions. One study treated $\mathrm{R} 6 / 1$ mice with a full $\mathrm{CB}_{1}$ agonist (HU210), a partial $\mathrm{CB}_{1}$ agonist (THC) and an inhibitor (URB597) of fatty acid amide hydrolase, an enzyme known to inactivate the prototypical endocannabinoid anandamide, and found that none of these treatments improved the motor phenotype of R6/1 mice (Dowie et al., 2010). Conversely, another study treated R6/2 mice with a lower concentration of THC ( $2 \mathrm{mg} / \mathrm{kg}$, compared with $10 \mathrm{mg} / \mathrm{kg}$ ) and found improvement in several motor and neuropathological measures (Blázquez et al., 2010). A caveat to pharmacological manipulation of $\mathrm{CB}_{1}$ receptors in $\mathrm{HD}$ mouse models is that systemic injection of agonists activates large populations of $\mathrm{CB}_{1}$ receptors irrespective of cell type, whereas $\mathrm{CB}_{1}$ signaling is lost only in select neuronal types. Specifically, in $\mathrm{R} 6 / 2$ mice, presynaptic $\mathrm{CB}_{1}$ signaling is down-regulated in MSN axon terminals, while it is preserved on corticostriatal terminals (Chiodi et al., 2012). Furthermore, in striatal interneurons, $\mathrm{CB}_{1}$ receptor expression and signaling is lost on NPY interneurons but not on cholinergic, parvalbumin or somatostatin interneurons (Horne et al., 2012). Therefore, the effects of delivering cannabinoid agonists systemically are difficult to interpret because of their action on multiple populations of $\mathrm{CB}_{1}$ receptors. Adding to this difficulty, the selectivity of cannabinoid drugs is limited by offtarget responses, including through $\mathrm{CB}_{2}$ receptors, TRPV1 and GPR55 (Abood et al., 2012). To circumvent these issues and directly test the physiopathological relevance of $\mathrm{CB}_{1(\mathrm{MSN})}$ dysfunction in $\mathrm{HD}$, we generated a conditional flox-stop $\mathrm{CB}_{1}$ knock-in mouse and 
backcrossed it to both the $\mathrm{Gpr} 88^{+/ \mathrm{Cre}}$ mouse line and to R6/2 mice, generating a new R6/2 mouse line in which an extra copy of $\mathrm{Cnrl}$ is selectively expressed in MSNs. Using this new genetic tool, we studied whether cell selective genetic rescue of $\mathrm{CB}_{1}$ signaling in MSNs affects characteristic motor behaviors and pathogenesis in R6/2 mice.

\section{RESULTS}

\section{Generation of $\mathrm{R} 6 / 2$ mice with genetic rescue of $\mathrm{CB}_{1}$ (MSN)}

We inserted a mouse $C n r l$ open reading frame between a loxP-flanked $P g k$-Neo resistance gene and ires EGFP, and then moved that cassette into a Gt(Rosa26)Sor targeting vector with the CBA promoter (CMV-chicken $\beta$-actin) at the transcription start (Figure 1A, Supplementary Figure 1). We refer to this modified $G t\left(\right.$ Rosa26)Sor locus as $R 26^{f_{\mathrm{fSCB}}}$. Females with this gene were bred with $\mathrm{Gpr} 88^{+/ \mathrm{Cre}}$ males that express Cre recombinase predominantly in MSNs to activate $\mathrm{CB}_{1}$ expression in MSNs (Quintana et al., 2012). Because low levels of GPR88 expression have been reported in other brain areas including the cortex, we performed PCR to verify that the excision of Pgk-Neo, and thus activation of the $\mathrm{fsCB}_{1}$ insert, does not occur in other brain regions. Confirming the regional selectivity of our construct, DNA from dissected striatum showed a band indicating Pgk-Neo excision, whereas DNA from tail, cortex and thalamus did not (Figure 1B).

Down-regulation of $\mathrm{CB}_{1}$ protein occurs first in the indirect pathway and later in the direct pathway in HD patients and mouse models (Glass et al., 2000). To verify the rescue of $\mathrm{CB}_{1}$ protein expression in R6/2 mice, we performed semi-quantitative IHC in the GP and $\mathrm{SNr}$, the respective targets of indirect- and direct-pathway MSNs. By co-staining for either LeuEnkephalin or Substance $\mathrm{P}$, we delineated regions of interest and measured $\mathrm{CB}_{1}$ protein expression as previously described (Horne et al., 2012). In the $\mathrm{GP}$ of $\mathrm{R} 6 / 2$ mice, $\mathrm{CB}_{1}$ protein was reduced to $64 \% \pm 12$ of wild-type (WT) levels ( $\mathrm{p}=0.003)$ and this down-regulation did not occur in $\mathrm{R} 6 / 2-\mathrm{CB}_{1(\mathrm{MSN})}$ mice $\left(\mathrm{F}_{(2,30)}=7.2, \mathrm{p}=0.003,91 \% \pm 10\right.$ of WT levels (Figure $1 \mathrm{C}, \mathrm{E}$, see Supplementary Figure 2 for details on image analysis). In the $\mathrm{SNr}$, we measured a trend towards loss of $\mathrm{CB}_{1}$ protein in $\mathrm{R} 6 / 2$ mice compared with $\mathrm{WT}$ or $\mathrm{R} 6 / 2-\mathrm{CB}_{1(\mathrm{MSN})}$ mice $\left(\mathrm{F}_{(2,28)}=1.9, \mathrm{p}=0.16\right)$ (Figure 1D). These results indicate that expression of the $R 2 \sigma_{\mathrm{fsCB} 1}$ allele rescues the expression of $\mathrm{CB}_{1}$ protein in MSNs. Because of the rapid disease progression of R6/2 mice, it is possible that these mice die before the full expression of the molecular phenotype (i.e. before $\mathrm{CB}_{1}$ protein loss occurs in the direct pathway).

\section{Knock-In $\mathrm{CB}_{1}$ receptors are functional}

To examine the functionality of $\mathrm{CB}_{1}$ receptors expressed from the $R 26^{\mathrm{fsCB} 1}$ allele, we bred this and the $\mathrm{Gpr} 88^{+/ \mathrm{Cre}}$ allele into a $\mathrm{Cnrl} \mathrm{I}^{-/-}$background. Here we used $\mathrm{Gpr} 88+/ \mathrm{Cre}$ females, which express Cre recombinase in the ova, to generate mice with global expression of $R 26^{\mathrm{fSCB} 1}$ allele as verified for all animals by PCR reaction from DNA dissected from tail, cortex, thalamus, or striatum (Figure $2 \mathrm{~A}$ ). To test whether these $\mathrm{CB}_{1}$ receptors functionally couple to $\mathrm{G}$ proteins, we performed a GTP $\gamma \mathrm{S}$-binding assay. First, we established the $\mathrm{EC}_{80}$ response induced by the $\mathrm{CB}_{1}$ receptor agonist CP55,940, as measured by increased $\mathrm{GTP} \gamma \mathrm{S}$ binding in freshly harvested SNr tissue from 5 WT mice (Figure 2B). In the next experiment, we harvested $\mathrm{SNr}$ tissue from WT, $\mathrm{Cnrl}^{-1-}$ or Global-fsCB $\mathrm{f}_{1}$ mice and 
performed $\mathrm{GTP} \gamma \mathrm{S}$ binding using the $\mathrm{EC}_{80}$ dose of $\mathrm{CP} 55,940$ (i.e. $140 \mathrm{nM}$, Figure $2 \mathrm{C}$ ).

Stimulation of GTP $\gamma \mathrm{S}$ binding in response to $\mathrm{CP} 55,940$ in $\mathrm{Global}_{-} \mathrm{fsCB}_{1}$ mice was similar to the response measured in WT levels when compared to $\mathrm{Cnrl}^{-1-}$ mice (WT: $148.5 \% \pm 7.3$, $\mathrm{Cnrl}^{-{ }^{-}}=104.5 \% \pm 10.5$, Global-fsCB $\left.1=133.4 \% \pm 2.7 ; \mathrm{F}_{(2,10)}=9.48, \mathrm{p}=0.005\right)$. As a secondary verification of $\mathrm{fsCB}_{1}$ receptor functionality, we tested the ability of Global-fs $\mathrm{fB}_{1}$ mice to reproduce characteristic motor response induced by cannabinoid agonists. Specifically, CP55,940-induced catalepsy was absent in $\mathrm{Cnrl}^{-1-}$ mice and rescued in Global-fsCB 1 mice (genotype: $\mathrm{F}_{(2,28)}=111.3, \mathrm{P}<0.001$; time: $\mathrm{F}_{(3,28)}=49.2$, $\mathrm{p}<.001$, interaction: $\left.\mathrm{F}_{(6,28)}=15.1, \mathrm{p}<0.001\right)(\mathrm{p}<0.001$ at 5 and $30 \mathrm{~min}, \mathrm{p}=0.02$ at $60 \mathrm{~min}$, Figure 2D). Similarly, CP55,940 induced hypolocomotion in both WT and Global-fsCB ${ }_{1}$ mice, whereas this response was absent in $\mathrm{Cnrl}^{-/-}$mice (interaction of genotypextreatment: $\mathrm{F}_{(2,18)}=29.58$, $\mathrm{p}<0.001$, Figure $2 \mathrm{E}$ ). We conclude that $\mathrm{fsCB}_{1}$-derived $\mathrm{CB}_{1}$ receptors functionally couple to $\mathrm{G}$ proteins and are sufficient to restore CP55,940-induced behaviors in mice lacking endogenous $\mathrm{CB}_{1}$ receptors.

\section{The $\mathrm{R} 6 / 2$ motor phenotype is unchanged by genetic rescue of $C B_{1(M S N)}$ receptors}

The effect of $\mathrm{CB}_{1(\mathrm{MSN})}$ rescue on $\mathrm{R} 6 / 2$ mice was tested using several indices of motor impairment. Rotarod performance showed a trend towards impairment at $4 \mathrm{wk}$ of age in both $\mathrm{R} 6 / 2$ and $\mathrm{R} 6 / 2-\mathrm{CB}_{1(\mathrm{MSN})}$ mice compared to WT mice, and was similarly impaired in both these lines at 8 weeks $\left(\mathrm{F}_{(2,8)}=25.7, \mathrm{p}<0.001\right)$ and 12 weeks of age $\left(\mathrm{F}_{(2,10)}=285.7, \mathrm{p}<0.001\right.$, Figure 3A). Locomotion was measured for $10 \mathrm{~min}$ in an open field chamber, and both R6/2 and $\mathrm{R} 6 / 2-\mathrm{CB}_{1(\mathrm{MSN})}$ rescue mice were similarly hypolocomotive compared to WT mice beginning at $10 \mathrm{wk}$ of age (Figure 3B). At 4 and $6 \mathrm{wk}, \mathrm{R} 6 / 2$ mice performed fewer rearings than $\mathrm{R} 6 / 2-\mathrm{CB}_{1(\mathrm{MSN})}$ mice and WT mice (pooled 4 and $6 \mathrm{wk}$ : WT $=16.5 \pm 2.2, \mathrm{R} 6 / 2=$ $\left.5.8 \pm 1.2, \mathrm{R} 6 / 2-\mathrm{CB}_{1(\mathrm{MSN})}=12.5 \pm 2.0\right)$, but at 8 weeks of age, $\mathrm{R} 6 / 2-\mathrm{CB}_{1(\mathrm{MSN})}$ mice were indistinguishable from R6/2 mice (as indicated by the fact that both groups reared much less than WT mice) (pooled 8, 10, and $12 \mathrm{wk}$ : WT $=16.25 \pm 0.8, \mathrm{R} 6 / 2=2.8 \pm 1.4, \mathrm{R} 6 / 2-\mathrm{CB}_{1(\mathrm{MSN})}$ $=2.6 \pm 1.0$, Figure $3 \mathrm{C}$ ). General measures of HD mouse impairment were scored biweekly by blinded observers for nine indices commonly measured in R6/2 mice (factors on a 1-2 scale, see methods). Two-factor ANOVA showed an effect of genotype $\left(\mathrm{F}_{(2,114)}=81.6, \mathrm{p}<0.001\right)$, and of age $\left(\mathrm{F}_{(4,114)}=24.6, \mathrm{p}<0.001\right)$ when comparing $\mathrm{WT}$ and R6/2 mice, and the interaction between genotype and age was also significant $\left(\mathrm{F}_{(8,114}=6.4, \mathrm{P}<0.001\right)$, reflecting a progressive motor phenotype in $\mathrm{R} 6 / 2$ mice. This measure of disease progression was unchanged between R6/2 and R6/2- $\mathrm{CB}_{1(\mathrm{MSN})}$ mice (Figure 3D). Similarly, clasping behavior showed an interaction between age and genotype $\left(\mathrm{F}_{(8,111)}=3.1, \mathrm{p}=0.003\right)$ and this measure was similarly impaired in $\mathrm{R} 6 / 2$ and $\mathrm{R} 6 / 2-\mathrm{CB}_{1(\mathrm{MSN})}$ mice compared to WT mice (Figure 3E).

To complement these measures of motor behavior, we performed automated gait analysis using the Noldus Catwalk XT system (Wageningen, The Netherlands). $\mathrm{R} 6 / 2-\mathrm{CB}_{1(\mathrm{MSN})}$ mice showed mild improvement in base of support $\left(\mathrm{F}_{(2,14)}=4.4\right.$, $\left.\mathrm{p}=0.03\right)$, step cycle $\left(\mathrm{F}_{(2,14)}=6.0\right.$, $\mathrm{p}=0.01)$ and print position $\left(\mathrm{F}_{(2,13)}=6.8, \mathrm{p}=0.01\right)$ compared with $\mathrm{R} 6 / 2$ mice (Figure $\left.3 \mathrm{~F}-\mathrm{H}\right)$ but no improvement in swing speed (forelimbs: $\mathrm{F}_{(2,14)}=8.31$, $\mathrm{p}<0.01$; hindlimbs: $\mathrm{F}_{(2,14)}=10.86$, $\mathrm{p}<0.01$ ), stride length (forelimbs: $\mathrm{F}_{(2,14)}=4.7, \mathrm{p}<0.03$; hindlimbs: $\mathrm{F}_{(2,14)}=11.4, \mathrm{p}<0.01$ ) or crossing speed $\left(\mathrm{F}_{(2,14)}=8.1, \mathrm{p}<0.01\right)$ (Figure 3I-K). Based on the battery of motor behavior 
testing analyzed here, we conclude that no appreciable motor rescue resulted from $\mathrm{CB}_{1(\mathrm{MSN})}$ in $\mathrm{R} 6 / 2$ mice.

\section{$\mathrm{CB}_{1(\mathrm{MSN})}$ receptor rescue is sufficient to prevent loss of excitatory synapses in striatum of $\mathrm{R} 6 / 2$ mice}

Previous studies have reported a loss of striatal synaptophysin in R6/2 mice (Cepeda et al., 2003). We found that $\mathrm{CB}_{1(\mathrm{MSN})}$ rescue was sufficient to prevent the loss of synaptophysin in both the dorsolateral and dorsomedial striatum (DL-STR: $\mathrm{F}_{(2,28)}=4.7$, $\mathrm{p}=0.018$; DM-STR: $\mathrm{F}_{(2,29)}=5.0, \mathrm{p}=0.013$ ) (Figure 4A-C). Furthermore, when levels of striatal synaptophysin were plotted against $\mathrm{CB}_{1}$ receptors in the GP (WT mice were excluded to prevent genotypedriven bias), we calculated a positive correlation $\left(\mathrm{r}^{2}=0.29, \mathrm{p}=0.045\right.$, slope $\left.=0.67 \pm 0.30\right)$ between loss of $\mathrm{CB}_{1}$ receptors and reduction in synaptophysin staining within individual mice (Figure 4D). To determine in greater detail which populations of synapses lose synaptophysin, we co-stained for either vesicular glutamate transporter 1 (vGLUT1) and vesicular glutamate transporter 2 (vGLUT2), markers of corticostriatal and thalamicostriatal synapses, or vesicular GABA transporter (vGAT) and Neuroligin-2, markers of GABAergic synapses. We observed decreased immunostaining in both vGLUT1 $\left(\mathrm{F}_{(2,25)}=5.45, \mathrm{p}=0.011\right)$ and vGLUT2 $\left(\mathrm{F}_{(2,25)}=7.01, \mathrm{p}=0.004\right)$ in the striatum of $\mathrm{R} 6 / 2$ mice compared to WT (vGLUT1: $\mathrm{p}=0.004$, vGLUT2: $\mathrm{p}=.002$ ), and found that both proteins remained at WT levels in R6/2-CB 1 (MSN) rescue mice (vGLUT1: $\mathrm{p}=0.012$; vGLUT2: $\mathrm{p}=0.005$, Fig. $5 \mathrm{~A}-\mathrm{C}$ ). As predicted by previous reports, vGAT and Neuroligin-2 levels were similar in WT and R6/2, and remained unchanged in $\mathrm{R} 6 / 2-\mathrm{CB}_{1(\mathrm{MSN})}$ rescue mice (Figure 5D-F) (Nithianantharajah et al., 2008). We conclude that excitatory, but not inhibitory, presynaptic proteins are lost in the striatum of $\mathrm{R} 6 / 2$ mice, and that genetic rescue of $\mathrm{CB}_{1(\mathrm{MSN})}$ is sufficient to prevent the selective loss of presynaptic glutamatergic markers.

To extend our IHC findings, we measured dendritic spine density in Golgi-stained sections. Indeed, prior work has shown that R6/2 mice exhibit a reduction in spine number which is most pronounced in higher-order dendrites (Klapstein et al., 2001; Spires et al., 2004). We reproduced this result, and extended it to show that genetic rescue of $\mathrm{CB}_{1(\mathrm{MSN})}$ is sufficient to prevent the reduction in MSN dendritic spine density in R6/2 mice (Figure 6). Dendritic spine density was different between genotypes $\left(\mathrm{F}_{(2,24)}=11.58, \mathrm{p}<0.001\right)$ and these differences were more pronounced with increasing branch order $\left(\mathrm{F}_{(6,72)}=3.81, \mathrm{p}=0.002\right)$. Specifically, spine density was unchanged between genotypes in first and second order dendrites, but spine density was reduced in R6/2 mice in third and fourth order dendrites compared to WT. This loss of spine density did not occur in $\mathrm{R} 6 / 2-\mathrm{CB}_{1(\mathrm{MSN})}$ mice (see supplementary Table 1 for specific values).

\section{Rescued excitatory striatal synapses are functional}

To determine if rescued excitatory striatal synapses are functional, we recorded spontaneous synaptic events by whole-cell voltage-clamp at $-70 \mathrm{mV}$ in the presence of $50 \mu \mathrm{M}$ picrotoxin to block $\mathrm{GABA}_{\mathrm{A}}$ mediated inhibitory events and isolate sEPSCs. As previously reported, we found that the frequency of sEPSCs in R6/2 MSNs was significantly reduced compared to WT ( $<<0.05$, Figure 7A) (Cepeda et al., 2003).We also found that sEPSC frequency in R6/2$\mathrm{CB}_{1(\mathrm{MSN})}$ mice was significantly greater than $\mathrm{R} 6 / 2(\mathrm{p}<0.05)$ and indistinguishable from WT. 
Note that we found no difference in the amplitude of sEPSC across genotypes indicating that the excitatory receptors mediating this response were not affected. Together, these results suggest that the number of functional excitatory synapses measured in $\mathrm{R} 6 / 2-\mathrm{CB}_{1(\mathrm{MSN})}$ is rescued to WT levels.

We measured MSN capacitance and input resistance by a $10 \mathrm{mV}$ depolarizing step from the membrane potential clamped at $-70 \mathrm{mV}$ after seal rupture. In concordance with previous studies (Cepeda et al., 2003), R6/2 MSN displayed reduced capacitance and increased input resistance compared to WT ( $p<0.001$ and $p<0.01$ respectively Figure 8 A and B). In contrast, the capacitance of MSNs from R6/2-CB 1 (MSN) was not reduced compared to WT and was greater than the capacitance of R6/2 MSN ( $p<0.05)$. The higher input resistance of R6/2 MSNs was also restored to WT levels in MSNs from R6/2-CB 1 (MSN) mice $(\mathrm{p}<0.001)$. Resting membrane potentials of MSNs and current-voltage curve were recorded in current clamp mode. Whereas R6/2 MSN were depolarized at rest compared to WT ( $<<0.01$, Fig $8 \mathrm{C}), \mathrm{R} 6 / 2-\mathrm{CB}_{1(\mathrm{MSN})}$ resting membrane potentials were similar to WT and had a lower membrane potential than R6/2 MSN ( $\mathrm{p}<0.05$ ). Somatic input current steps resulted in changes in membrane potential that were greater magnitude in MSNs of both R6/2 and $\mathrm{R} 6 / 2-\mathrm{CB}_{1(\mathrm{MSN})}$ mice compared to WT mice, indicating no rescue of this measure (Fig 8E). Specifically, the relationship between spiking frequency and injected current was shifted leftward in $\mathrm{R} 6 / 2$ and $\mathrm{R} 6 / 2-\mathrm{CB}_{1(\mathrm{MSN})}$ genotypes compared to WT (Figure $8 \mathrm{D}, \mathrm{P}<0.001$ ), but only intrasomatic injection of a 150pA current step produced more action potentials over 1 sec in R6/2 MSN (mean= 19.6 +/- 1.7) compared to WT MSN (mean=11.5+/-2.6 p<0.05). Additionally, Rheobase current was significantly lower in both $\mathrm{R} 6 / 2(78.26+/-6.15, \mathrm{n}=23$, $\mathrm{p}<0.001)$ and $\mathrm{R} 6 / 2-\mathrm{CB}_{1(\mathrm{MSN})}(81.82+/-10.16, \mathrm{n}=11, \mathrm{p}<0.05)$ compared to WT $(116.7+/-$ $8.33, \mathrm{n}=9$ ). In summary, passive membrane properties including capacitance, input resistance and membrane potential of $\mathrm{R} 6 / 2-\mathrm{CB}_{1(\mathrm{MSN})}$ were restored to WT levels, whereas the response to somatic current injection and action potential thresholds in MSNs of R6/2$\mathrm{CB}_{1(\mathrm{MSN})}$ mice remained impaired compared to WT mice.

\section{DISCUSSION}

Here we show that the genetic rescue of $\mathrm{CB}_{1(\mathrm{MSN})}$ receptors in $\mathrm{R} 6 / 2$ mice prevents the loss of excitatory input to the striatum as indicated by the sparing of excitatory synaptic proteins (synaptophysin, vGLUT1 and vGLUT2), as well as dendritic spine density on MSNs, as measured by Golgi staining. We confirm these anatomical findings by demonstrating a rescue of sEPSC frequency in MSNs, suggesting that rescued excitatory synapses are functional. Additionally, we measured changes in the intrinsic properties of MSNs that are consistent with changes in the density of dendritic spines, since neither soma size nor dendritic arbors are affected in R6/2 mice (Spires et al., 2004). However, genetic rescue of $\mathrm{CB}_{1(\mathrm{MSN})}$ did not rescue all impairments of MSN physiology, as active properties (I-V relationship, rheobase) remained compromised in $\mathrm{R} 6 / 2-\mathrm{CB}_{1(\mathrm{MSN})}$ mice. We also found that inhibitory synaptic proteins are unaffected in R6/2 mice, confirming previous studies reporting reductions in both GluR1 and PSD95, but not gephryn, in the striatum of R6/1 mice (Nithianantharajah et al., 2008) and reduction of PSD95 in R6/2 mice (Luthi-Carter et al., 2003). 
Despite the reversal of synaptopathy among striatal inputs, the $\mathrm{R} 6 / 2-\mathrm{CB}_{1(\mathrm{MSN})}$ mice did not show improvement in motor phenotype among a battery of behavioral measures.

Importantly, reduced sEPSCs are only one of many electrophysiological disturbances that have been described in the striatum of R6/2 mice (Raymond et al., 2011). Specifically, reduced connectivity between MSNs (Cepeda et al., 2013), abnormal increase in MSN responses to input from fast-spiking interneurons (Cepeda et al., 2013), alterations in GABA synaptic transmission (Centonze et al., 2005) and impaired dopamine-dependent long-term potentiation (Kung et al., 2007) have been reported in R6/2 mice, any combination of which are likely to contribute to the motor phenotype observed in this model. This body of evidence emphasizes the notion that multiple circuits are impaired in R6/2 mice and that it is likely their summation that produces a behavioral phenotype. Our results extend this notion by showing that striatal excitatory synaptic loss and rescue can be uncoupled from motor deficits in HD.

Several likely mechanisms might be considered with regard to the $\mathrm{CB}_{1(\mathrm{MSN})}$-mediated sparing of excitatory striatal synapses. Activation of $\mathrm{CB}_{1}$ receptors regulates the release of GABA from MSN terminals; therefore the early loss of $\mathrm{CB}_{1}$ receptors from indirectpathway MSN terminals in R6/2 mice may cause imbalanced output from the basal ganglia to the thalamus and cortex that likely alters excitatory input to the striatum (Kreitzer and Malenka, 2008). Additionally, it has been recently shown that silencing direct- or indirectpathway MSNs controls the number of excitatory synapses onto MSNs while having no effect on their arborization (Kozorovitskiy et al., 2012). Thus $\mathrm{CB}_{1(\mathrm{MSN})}$ on MSN-MSN collaterals may affect the inhibitory tone of MSN recurrent network activity, which seems to control striatal inputs.

Interest in targeting the eCB system for therapeutic intervention in HD originally arose from the realization that $\mathrm{CB}_{1(\mathrm{MSN})}$ receptors are selectively lost in HD patients early in disease (Glass et al., 2000), a landmark observation that inspired the hypothesis that this loss constitutes a key pathogenic event which culminates in behavioral impairment (Blázquez et al., 2010). Our results do not support this hypothesis, as we did not observe an improvement of behavioral phenotype in response to $\mathrm{CB}_{1(\mathrm{MSN})}$ rescue. Instead, we report that rescue of $\mathrm{CB}_{1(\mathrm{MSN})}$ receptors prevents a very selective component of striatal synaptopathy, demonstrating that $\mathrm{CB}_{1(\mathrm{MSN})}$ signaling controls a subset of the anatomical and functional disturbances in HD mouse models. Our results also challenge the hypothesis that loss of $\mathrm{CB}_{1}$ receptors in MSNs represents a compensatory mechanism that reduces neuronal damage associated with $\mathrm{HD}$. Specifically, if $\mathrm{CB}_{1}$ loss was a compensatory event, then the expectation would be that $\mathrm{CB}_{1(\mathrm{MSN})}$ rescue should exacerbate at least some elements of the disease phenotype. In sharp contrast to this assumption, the electrophysiological and neuropathological data presented in our study show a rescue of excitatory synapse loss. Importantly, our data do not rule out the therapeutic use of cannabinoid agonists in HD, since other populations of $\mathrm{CB}_{1}$ receptors expressed by different neuronal types may be useful targets for controlling aberrant neurotransmission, especially $\mathrm{CB}_{1}$ receptors on the corticostriatal synapse which are spared and likely to regulate excitotoxicity (Chiodi et al., 2012). Specifically, two independent groups found that knockout of $C_{B}$ receptors in $R 6 / 2$ mice worsened the motor phenotype (Blázquez et al., 2010; Mievis et al., 2011) and a recent study identified the population of $\mathrm{CB}_{1}$ receptors expressed on glutamatergic terminals as 
solely responsible for exacerbation of the $\mathrm{R} 6 / 2$ motor phenotype in response to $\mathrm{CB}_{1}$ deletion (Chiarlone et al., 2014).

In summary, our study has addressed a long-standing question in the field regarding the pathogenic significance of the loss of $\mathrm{CB}_{1(\mathrm{MSN})}$ receptors in $\mathrm{HD}$, by demonstrating a specific role for $\mathrm{CB}_{1 \text { (MSN) }}$ dysregulation in the loss of excitatory synapses in the striatum. Further work remains to be done to elucidate the molecular, cellular and network details underlying the control of functional excitatory synapses in the striatum by $\mathrm{CB}_{1(\mathrm{MSN})}$ receptors.

\section{MATERIALS AND METHODS}

\section{Mice}

Mice were housed in a specific pathogen-free facility in accordance with the National Institutes of Health; the Institutional Animal Care and Use Committee at the University of Washington approved all experiments. Enrichment and ad-libitum access to food and water was provided and a 12-hr light/dark cycle was maintained in the facility. R6/2 and WT littermates were given a wet food mash in addition to dry pellets beginning at 10 weeks of age. Both female and male R6/2, R6/2-CB $1(\mathrm{MSN})$ rescue, and WT littermates were used in this study. The colony was maintained by breeding 6- to 8 -week-old $\mathrm{R} 6 / 2-G p r 88^{+/ \mathrm{Cre}}$ males with $R 26^{+/ \mathrm{fsCB} 1}$ females, and all animals were on a 50:50 CBA, C57B1/6 background. The average CAG repeat length of our colony is $114.1 \pm 0.3(\mathrm{n}=10)$ and was determined by PCR from tail snips by Laragen, Inc [Culver City, CA, USA]. Genotyping was performed as follows: 1) $\mathrm{fsCB}_{1}$ using primers aaagtcgctctgagttgttatcag (P1), ggagcgggagaaatggatatg (P2) and tcactgcattctagttgtggtttg (P3) with ThermoPol Buffer (NE Biolabs, MA); 2) pgk-neo with primers ctctgctaaccatgttcatgcc (P4) and tctgcaaggccgtctaagat (P5) using ThermoPol Buffer (NE Biolabs, MA); 3) Gpr88Cre with tggaggaacgaggagttccgc (1569) and agaaggaggcagtgcggcagg (1570) using Phusion (NE Biolabs, MA); 4) R6/2 with primers cgcaggctgcagggttac and gctgcaccgaccgtgagt using Lightcycler 480 Master (Roche, Basel, Switzerland).

\section{Generation of $\mathrm{fsCB}_{1}$ mice}

The open reading frame of mouse Cnrl was inserted between a loxP-flanked Pgk-Neo gene and ires EGFP in a transfer plasmid. This flox'd Pgk-Neo-Cnrl-ires-EGFP insert was then moved into a targeting vector that has the CBA promoter inserted at the transcription start site of the $G t\left(\right.$ Rosa26) ${ }^{\text {Sor }}$ locus and contains $7.7 \mathrm{~kb}$ of 5' flanking and $4.1 \mathrm{~kb}$ of 3' flanking $G t\left(\right.$ Rosa26) ${ }^{\text {Sor }}$ sequence and a PgK-DTa gene for negative selection. This construct was linearized and electroporated into G4 embryonic stem cells. Correct gene targeting was determined by Southern blot of DNA digested with Ndel using a probe that lies outside of the targeting vector. Correctly targeting ES cells were injected into the blastocyst of C57B1/6 recipients and chimeric pups were bred with $\mathrm{C} 57 \mathrm{Bl} / 6$ mice.

\section{$\left[{ }^{35} \mathrm{~S}\right] \mathrm{GTP} \gamma \mathrm{S}$ Binding Assay}

$\mathrm{SNr}$ tissue was rapidly dissected on ice and immediately homogenized in ice-cold $50 \mathrm{mM}$ Tris- $\mathrm{HCl}$ (pH 7.4), $3 \mathrm{mM} \mathrm{MgCl}_{2}$, and $1 \mathrm{mM}$ EGTA. The homogenate was centrifuged at 
$45,000 \times \mathrm{g}$ for $10 \mathrm{~min}$ at $4^{\circ} \mathrm{C}$, and then the pellet was homogenized in $50 \mathrm{mM}$ Tris- $\mathrm{HCl}$, with $3 \mathrm{mM} \mathrm{MgCl}_{2}, 1 \mathrm{mM}$ EGTA and $100 \mathrm{mM} \mathrm{NaCl}$. The resulting membrane homogenate was pre-incubated with $3 \mathrm{mU} / \mathrm{ml}$ adenosine deaminase (Roche Applied Science, IN) for $10 \mathrm{~min}$ at $30^{\circ} \mathrm{C}$, to inactivate endogenous adenosine. Then, $10 \mu ; \mathrm{g}$ of protein per reaction was incubated in reaction buffer containing $0.1 \% \mathrm{BSA}, 30 \mu \mathrm{M}$ GDP, $0.1 \mathrm{nM}\left[{ }^{35} \mathrm{~S}\right] \mathrm{GTP} \gamma \mathrm{S}$ (Perkin Elmer, OH) and $0.6 \mathrm{mU} / \mathrm{ml}$ adenosine deaminase, with either $140 \mu \mathrm{M} \mathrm{CP55,940} \mathrm{or}$ vehicle, for $45 \mathrm{~min}$ at $30^{\circ} \mathrm{C}$. The incubation was terminated by vacuum filtration through Whatman filters (GE Healthcare), followed by three washes with $3 \mathrm{ml}$ ice-cold Tris- $\mathrm{HCl}, \mathrm{pH}$ 7.4. Bound $\left[{ }^{35} \mathrm{~S}\right] \mathrm{GTP} \gamma \mathrm{S}$ was quantified using a liquid scintillation counter in vials containing isolated $\left[{ }^{35} \mathrm{~S}\right] \mathrm{GTP} \gamma \mathrm{S}$-bound filter paper along with $4 \mathrm{ml}$ of Ecoscint scintillation fluid (National Diagnostics).

\section{Behavioral Studies}

Balanced cohorts of males and females were used for behavioral studies. All behavioral tests were performed during the light phase of the light/dark cycle, between 9 am and $12 \mathrm{pm}$. All cages were cleaned with 70\% ethanol between trials, and then dried with a paper towel. At 6 weeks of age, mice were tested for hypothermia, hypolocomotion, catalepsy and analgesia, both before and after injection of $0.3 \mathrm{mg} / \mathrm{kg}$ CP55,940. Core body temperature was measured by anal probe. Hypolocomotion was measured in an open field chamber $(25 \mathrm{~cm} \times$ $45 \mathrm{~cm}$ plexiglass cage) for $10 \mathrm{~min}$ starting $30 \mathrm{~min}$ after injection. Data were collected by vertically mounted video cameras and videos were analyzed in Ethovision 9.0 (Noldus, Wageningen, The Netherlands). Center-point tracking with dynamic- background subtraction was use to acquire the track for each animal. Catalepsy was measured by placing the animals' front paws on a horizon bar approximately $3 \mathrm{~cm}$ high and recording the latency to remove the paws from the bar. An average of four trials was used per animal, and measurements were made both before and 30 min post-injection. Tail flick analgesia was measured by placing $1 \mathrm{~cm}$ of the tail in a $55^{\circ} \mathrm{C}$ water bath $\left(+/-2^{\circ} \mathrm{C}\right)$, and measuring the latency to tail withdrawal. Rotarod (Columbus Instruments, $\mathrm{OH}$ ) testing included a 5-min training period on the rotarod at 5 RPM, after which mice were rested and then began 7 consecutive trials, separated by 30-min resting periods. The rotarod rotational speed used for the test trials began at $4 \mathrm{rpm}$ and increased to $40 \mathrm{rpm}$, with an acceleration of $0.2 \mathrm{rpm}$ per every 4 sec. Catwalk testing was performed at 10 weeks of age: animals were placed at one end of the Catwalk apparatus (Noldus, Wageningen, Netherlands), with a vertically mounted camera beneath the catwalk and five crossings were analyzed for each animal. Crossings where the animal stopped, reared, or turned around were excluded. Phenotype was manually scored biweekly from 4-12 wk in an open-field chamber to generate a phenotype index and to count rearings. Animals were placed in a $25 \mathrm{~cm} \times 45 \mathrm{~cm}$ plexiglass cage for $2 \mathrm{~min}$ and were scored from 1-2 on 9 measures (tremor, body position, tail position, piloerection, exploration of all 4 corners, observed seizures, presence of hindlimb clasping, palpebral closure, and grooming), such that the possible scores ranged from 9-18, with increasing score indicating pathological phenotype. Open field testing was performed in a and mice were allowed to explore for $10 \mathrm{~min}$. 


\section{Immunohistochemistry and confocal microscopy}

Mice were perfused with $20 \mathrm{~mL}$ sterile PBS, followed by $10 \mathrm{~mL} 4 \%$ paraformaldehyde.

Brains were extracted, post-fixed overnight at $4{ }^{\circ} \mathrm{C}$ in $4 \%$ paraformaldehyde, then successively dehydrated in $15 \%$ sucrose and $30 \%$ sucrose for $24 \mathrm{hr}$ each, and finally frozen. Coronal sections were cut on a freezing microtome to a thickness of $30 \mu \mathrm{m}$, placed in cryoprotectant and stored at $-20^{\circ} \mathrm{C}$. On the day of staining, 2 slices per mouse were removed from cryoprotectant, washed $3 \times$ in PBS, and then incubated in blocking buffer (1\% Triton X-100, 5\% donkey serum in PBS) for $90 \mathrm{~min}$ at room temperature, and then transferred to primary staining solution ( $0.5 \%$ Triton X-100, 2.5\% donkey serum in PBS) for $72 \mathrm{hr}$ at $4^{\circ} \mathrm{C}$. Primary antibodies and dilutions used: $\mathrm{CB}_{1}$, guinea pig, gift from Ken Mackie; leu-enkephalin, rabbit, Millipore AB5024; substance P, rabbit, Millipore AB1566; vGAT, mouse, Synaptic Systems 131011; vGlut1, mouse, Synaptic Systems 135311; vGlut2, rabbit, Invitrogen 42-7900; neuroligin2, rabbit, Synaptic Systems 129203. All primary antibodies were optimized by performing a dilution curve paired with quantitative analysis, and dilutions in the linear phase were chosen for further staining. After primary staining, sections were washed $8 \times$ in PBS-T for 5 min. Secondary staining was performed in $0.5 \%$ Triton X-100, 2.5\% donkey serum in PBS, using Alexa secondary antibodies at a dilution of 1:500. After secondary staining, sections were washed 6 times in PBS-T for 10 min, once in PBS, and then mounted with Fluoromount (Sigma, St Louis, MO) and sealed with nail polish.

Images were collected on a Leica SL confocal microscope equipped with a $63 \times($ N.A. $=1.40)$ oil immersion objective and with a $64 \mathrm{~mW}$ argon laser with lines at 457 and 488, a $10 \mathrm{~mW}$ helium-neon laser with a $543 \mathrm{~nm}$ line, and a $10 \mathrm{~mW}$ helium-neon laser with a $633 \mathrm{~nm}$ line. Optical sections were taken with the pinhole set at $1.0 \mathrm{AU}$, or $1.25 \mu \mathrm{m}$, with a resulting xy resolution of $0.163 \mu \mathrm{m}$ and a $\mathrm{z}$ resolution of $0.290 \mu \mathrm{m}$. Noise reduction was achieved by averaging three scans for each image, after verification that this method did not result in any measurable bleaching (Alexa dyes were used). Laser power was optimized to the brightest section for each stain, so that $>99 \%$ of pixels were within the linear range, and 12-bit images were collected.

\section{Semi-Quantitative Image Analysis and Statistics}

All images were analyzed and quantified in ImageJ (National Institutes of Health), using custom written macros which were applied blindly to each batch of images, and analyzed as previously reported (Horne et al., 2012). Each channel was split into an individual image and the mean intensity and standard deviation of each fluorophore in each image was measured. Background signal was removed by thresholding images to mean + standard deviation, corresponding to the top third brightest pixels in the Gaussian distribution. After thresholding, final measurements were made by taking the mean intensity of the (top-third) pixels which passed thresholding. Threshold values were validated by a human observer for each stain, to verify that pixels passing threshold corresponded to actual staining (threshold was not too low), and that actual staining was not being lost in thresholding (threshold was not too high). Statistical analysis and graphs were generated using GraphPad PRISM (San Diego, CA, USA). One-way ANOVAs were used for group comparisons and Fisher's T-test was used for post-hoc tests unless otherwise specified. 


\section{Golgi Staining and analysis}

Brains were cut in half at the midline and immediately placed in formaldehyde/ glutaraldehyde fixative (BioEnno, Irvine CA) for 5 hours. Fixative was changed once after $30 \mathrm{~min}$. After fixation, brains were stored in $0.1 \mathrm{M}$ phosphate buffer for a maximum of 5 days at $4{ }^{\circ} \mathrm{C}$. Brains were sliced to $100 \mu \mathrm{m}$ at room temperature on a vibratome (EMS, Hatfield PA) and striatal slices were collected in PBS. On-slice Golgi staining was performed using a SliceGolgi kit (BioEnno, Irvine CA). Staining was performed according to the kit protocol, using a 6-day Golgi impregnation. Slices were mounted on glass slides and allowed to dry for $24 \mathrm{hrs}$, then dehydrated in $100 \% \mathrm{EtOH}$, and cleared in xylenes. Slides were coverslipped using a 1:1 mixture of xylenes and Permount, and were allowed to dry for $48 \mathrm{hrs}$. Slides were imaged immediately after the drying period on a Marianas Live Cell Imaging System (Intelligent Imaging Innovations, Denver, CO) equipped with an automated stage, using a $100 \times$ oil objective. Montage z-series images were collected and aligned in SlideBook V5.5, and then exported as 16 bit TIF files. Manual counting of dendritic spines was performed in ImageJ (National Institutes of Health) using the multi-point selection tool with zstacked montages, and $x-y-z$ coordinates of each marked dendritic spine were recorded.

\section{Electrophysiology}

Procedures were performed in accordance with the Canadian Council on Animal Care and UBC Animal Care Committee regulations. Animals were deeply anesthetized with halothane vapor, decapitated and the brain rapidly removed. Acute sagittal brain slices $(300 \mu \mathrm{m})$ containing the dorso-lateral striatum were cut on a vibratome (Leica VT1000) in ice-cold aCSF (with Ca:Mg at 1:5) equilibrated with $95 \% \mathrm{O}_{2} / 5 \% \mathrm{CO}_{2}$. Slices were transferred to a holding chamber with aCSF (Ca:Mg 2:1) at $37^{\circ} \mathrm{C}$ containing (in $\mathrm{mM}$ ): $125 \mathrm{NaCl}, 2.5 \mathrm{KCl}$, $25 \mathrm{NaHCO}_{3}, 1.25 \mathrm{NaH}_{2} \mathrm{PO}_{4}, 1 \mathrm{MgCl}_{2}, 2 \mathrm{CaCl}_{2}, 25$ glucose, pH 7.3-7.4, 300-310 mosmol $\mathrm{L}^{-1}$ for $45 \mathrm{~min}$ then maintained at room temperature. In the recording chamber, slices equilibrated for 10 min continuously superfused at room temperature with oxygenated aCSF at $1-2 \mathrm{ml} / \mathrm{min}$ containing picrotoxin $(50 \mu \mathrm{M}$, Tocris Bioscience, MO, USA) to block $\mathrm{GABA}_{\mathrm{A}}$ receptor mediated inhibitory responses.

Whole cell patch-clamp recordings were performed from visualized MSN in the dorsal striatum. Glass electrodes (resistance 4-6 MOhms) were filled with internal solution as follows (mM): $128 \mathrm{~K}+$ Gluconate, $20 \mathrm{NaCl}, 1 \mathrm{MgCl}_{2}, 1$ EGTA, $0.3 \mathrm{CaCl}_{2}, 2 \mathrm{Na} 2+\mathrm{ATP}, 0.3$ $\mathrm{Na}+$ GTP, buffered with 10 Hepes, pH 7.3, osmolarity 290-300 mOsm. Data were acquired with a Multiclamp700 amplifier and Clampfit 10 software (Molecular Devices), digitized at $20 \mathrm{kHz}$ and filtered at $2 \mathrm{kHz}$. Immediately after breaking into the cell the capacitance, membrane resistance and access resistance was measured. Access resistance was uncompensated and cells were rejected if it was $>25 \mathrm{MOhms}$. Resting membrane potential and current voltage (I-V) curves in MSNs were made in current clamp mode by a series of hyperpolarizing to depolarizing current steps. Spontaneous excitatory post-synaptic currents (sEPSCs) were recorded in whole-cell voltage clamp configuration for a minimum of $4 \mathrm{~min}$ at $-70 \mathrm{mV}$. All data represents the mean $+/-\mathrm{SEM}$ of $\mathrm{n}=$ neurons from a minimum of 4 animals. Statistical analyses were made by two-way ANOVA for repeated measures or oneway ANOVA for group comparisons as indicated. 


\section{Supplementary Material}

Refer to Web version on PubMed Central for supplementary material.

\section{Acknowledgments}

We are grateful to Dr. Yi Hsing Lin for technical assistance with the generation of the $\mathrm{fsCB}_{1}$ construct. The CHDD Behavioral Core (Dr. Toby Cole and Dr. Sean Murphy, P30HD02274) provided both expertise and access to equipment used in the study, the KECK Microscopy Center (Dr. Greg Martin) provided access to a Leica Laser Scanning Microscope, and the Digital Microscopy Center (Dr. Glen MacDonald, HD002274) provided both expertise and access to the Marianas Live Cell Imaging Microscope. Finally, we are grateful for helpful discussions with the UW Statistical Consult Service. This work was funded by NIH (RO1-DA026430) and CHDI (NS, LAR), T32-GM007108 (AN), F30-DA033747 (AN), ARCS Seattle (AN), and the Canadian Institutes of Health Research (MOP-12699 to LAR).

\section{REFERENCES}

Abood, ME.; Sorensen, RG.; Stella, N. endoCANNABINOIDS: actions at Non-CB1/CB2 cannabinoid receptors. Springer; 2012.

Blázquez C, Chiarlone A, Sagredo O, Aguado T, Pazos MR, Resel E, Palazuelos J, Julien B, Salazar M, Börner C, Benito C, Carrasco C, Diez-Zaera M, Paoletti P, Díaz-Hernández M, Ruiz C, Sendtner M, Lucas JJ, de Yébenes JG, Marsicano G, Monory K, Lutz B, Romero J, Alberch J, Ginés S, Kraus J, Fernández-Ruiz J, Galve-Roperh I, Guzmán M. Loss of striatal type 1 cannabinoid receptors is a key pathogenic factor in Huntington's disease. Brain. 2010; 134:119-136. [PubMed: 20929960]

Centonze D, Rossi S, Prosperetti C, Tscherter A, Bernardi G, Maccarrone M, Calabresi P. Abnormal Sensitivity to Cannabinoid Receptor Stimulation Might Contribute to Altered GammaAminobutyric Acid Transmission in the Striatum of R6/2 Huntington's Disease Mice. Biol. Psychiatry. 2005; 57:1583-1589. [PubMed: 15953496]

Cepeda C, Galvan L, Holley SM, Rao SP, Andre VM, Botelho EP, Chen JY, Watson JB, Deisseroth K, Levine MS. Multiple Sources of Striatal Inhibition Are Differentially Affected in Huntington's Disease Mouse Models. Journal of Neuroscience. 2013; 33:7393-7406. [PubMed: 23616545]

Cepeda C, Hurst RS, Calvert CR, Hernández-Echeagaray E, Nguyen OK, Jocoy E, Christian LJ, Ariano MA, Levine MS. Transient and progressive electrophysiological alterations in the corticostriatal pathway in a mouse model of Huntington's disease. J. Neurosci. 2003; 23:961-969. [PubMed: 12574425]

Chiarlone A, Bellocchio L, Blazquez C, Resel E, Soria-Gomez E, Cannich A, Ferrero JJ, Sagredo O, Benito C, Romero J, Sanchez-Prieto J, Lutz B, Fernández-Ruiz J, Galve-Roperh I, Guzmán M. A restricted population of CB1 cannabinoid receptors with neuroprotective activity. Proc Natl Acad Sci USA. 2014; 111:8257-8262. [PubMed: 24843137]

Chiodi V, Uchigashima M, Beggiato S, Ferrante A, Armida M, Martire A, Potenza RL, Ferraro L, Tanganelli S, Watanabe M, Domenici MR, Popoli P. Unbalance of CB1 receptors expressed in GABAergic and glutamatergic neurons in a transgenic mouse model of Huntington's disease. Neurobiology of Disease. 2012; 45:983-991. [PubMed: 22207189]

Dowie MJ, Bradshaw HB, Howard ML, Nicholson LFB, Faull RLM, Hannan AJ, Glass M. Altered $\mathrm{CB} 1$ receptor and endocannabinoid levels precede motor symptom onset in a transgenic mouse model of Huntington's disease. Neuroscience. 2009; 163:456-465. [PubMed: 19524019]

Dowie MJ, Howard ML, Nicholson LFB, Faull RLM, Hannan AJ, Glass M. Behavioural and molecular consequences of chronic cannabinoid treatment in Huntington's disease transgenic mice. Neuroscience. 2010; 170:324-336. [PubMed: 20600638]

Eidelberg D, Surmeier DJ. Brain networks in Huntington disease. J. Clin. Invest. 2011; 121:484-492. [PubMed: 21285521]

Glass M, Dragunow M, Faull RL. The pattern of neurodegeneration in Huntington"s disease: a comparative study of cannabinoid, dopamine, adenosine and GABA(A) receptor alterations in the human basal ganglia in Huntington"s disease. Neuroscience. 2000; 97:505-519. [PubMed: 10828533] 
Glass M, van Dellen A, Blakemore C, Hannan AJ, Faull RLM. Delayed onset of huntington's disease in mice in an enriched environment correlates with delayed loss of cannabinoid CB1 receptors. Neuroscience. 2004; 123:207-212. [PubMed: 14667455]

Herkenham M, Lynn AB, Little MD, Johnson MR, Melvin LS, de Costa BR, Rice KC. Cannabinoid receptor localization in brain. Proceedings of the National Academy of Sciences. 1990; 87:19321936.

Horne EA, Coy J, Swinney K, Fung S, Cherry AET, Marrs WR, Naydenov AV, Lin YH, Sun X, Dirk Keene C, Grouzmann E, Muchowski P, Bates GP, Mackie K, Stella N. Downregulation of cannabinoid receptor 1 from neuropeptide $\mathrm{Y}$ interneurons in the basal ganglia of patients with Huntington's disease and mouse models. Eur J Neurosci. 2012; 37 n/a-n/a.

Katona I, Freund TF. Endocannabinoid signaling as a synaptic circuit breaker in neurological disease. Nat Med. 2008; 14:923-930. [PubMed: 18776886]

Klapstein GJ, Fisher RS, Zanjani H, Cepeda C, Jokel ES, Chesselet M-F, Levine MS. Electrophysiological and morphological changes in striatal spiny neurons in R6/2 Huntington's disease transgenic mice. Journal of Neurophysiology. 2001; 86:2667-2677. [PubMed: 11731527]

Kozorovitskiy Y, Saunders A, Johnson CA, Lowell BB, Sabatini BL. Recurrent network activity drives striatal synaptogenesis. Nature. 2012:1-8.

Kreitzer AC, Malenka RC. Striatal Plasticity and Basal Ganglia Circuit Function. Neuron. 2008; 60:543-554. [PubMed: 19038213]

Kung VWS, Hassam R, Morton AJ, Jones S. Dopamine-dependent long term potentiation in the dorsal striatum is reduced in the R6/2 mouse model of Huntington's disease. Neuroscience. 2007; 146:1571-1580. [PubMed: 17478055]

Luthi-Carter R, Apostol BL, Dunah AW, DeJohn MM, Farrell LA, Bates GP, Young AB, Standaert DG, Thompson LM, Cha J-HJ. Complex alteration of NMDA receptors in transgenic Huntington's disease mouse brain: analysis of mRNA and protein expression, plasma membrane association, interacting proteins, and phosphorylation. Neurobiology of Disease. 2003; 14:624-636. [PubMed: 14678777]

Maccarrone M, BATTISTA N, Centonze D. The endocannabinoid pathway in Huntington's disease: A comparison with other neurodegenerative diseases. Prog Neurobiol. 2007; 81:349-379. [PubMed: 17276576]

Mievis S, Blum D, Ledent C. Worsening of Huntington disease phenotype in CB1 receptor knockout mice. Neurobiology of Disease. 2011; 42:524-529. [PubMed: 21406230]

Nithianantharajah J, Barkus C, Murphy M, Hannan AJ. Gene-environment interactions modulating cognitive function and molecular correlates of synaptic plasticity in Huntington's disease transgenic mice. Neurobiology of Disease. 2008; 29:490-504. [PubMed: 18165017]

Pouladi MA, Stanek LM, Xie Y, Franciosi S, Southwell AL, Deng Y, Butland S, Zhang W, Cheng SH, Shihabuddin LS, Hayden MR. Marked differences in neurochemistry and aggregates despite similar behavioural and neuropathological features of Huntington disease in the full-length BACHD and YAC128 mice. Hum Mol Genet. 2012; 21:2219-2232. [PubMed: 22328089]

Quintana A, Sanz E, Wang W, Storey GP, Güler AD, Wanat MJ, Roller BA, La Torre A, Amieux PS, McKnight GS, Bamford NS, Palmiter RD. Lack of GPR88 enhances medium spiny neuron activity and alters motor- and cue-dependent behaviors. Nature Publishing Group. 2012; 15:1547-1555.

Raymond LA, Andre VM, Cepeda C, Gladding CM, Milnerwood AJ, Levine MS. REVIEWPATHOPHYSIOLOGY OF HUNTINGTON'S DISEASE: TIME-DEPENDENT ALTERATIONS IN SYNAPTIC AND RECEPTOR FUNCTION. NSC. 2011; 198:252-273.

Spires TL, Grote HE, Garry S, Cordery PM, Van Dellen A, Blakemore C, Hannan AJ. Dendritic spine pathology and deficits in experience- dependent dendritic plasticity in R6/1 Huntington's disease transgenic mice. Eur J Neurosci. 2004; 19:2799-2807. [PubMed: 15147313]

Woodman B, Butler R, Landles C, Lupton MK, Tse J, Hockly E, Moffitt H, Sathasivam K, Bates GP. The Hdh(Q150/Q150) knock-in mouse model of HD and the R6/2 exon 1 model develop comparable and widespread molecular phenotypes. Brain Research Bulletin. 2007; 72:83-97. [PubMed: 17352931] 


\section{ABBREVIATIONS}

$\mathbf{C B}_{1 \text { (MSN) }}$ refers to $\mathrm{CB}_{1}$ receptors expressed on medium spiny neurons

DL-STR dorsal-lateral striatum

DM-STR dorsal-medial striatum

HD Huntington's disease

MSN medium spiny neuron

SEPSC spontaneous excitatory post-synaptic current

vGAT vesicular GABA transporter

vGLUT1 vesicular glutamate transporter 1

vGLUT2 vesicular glutamate transporter 2 


\section{Highlights}

- Genetic rescue of $\mathrm{CB}_{1}$ receptors on medium spiny neurons in $\mathrm{HD}$ mice prevents loss of striatal excitatory synapses.

- Rescued excitatory synapses are functional.

- Loss of striatal excitatory synapses can be uncoupled from HD motor phenotype. 


\section{A}

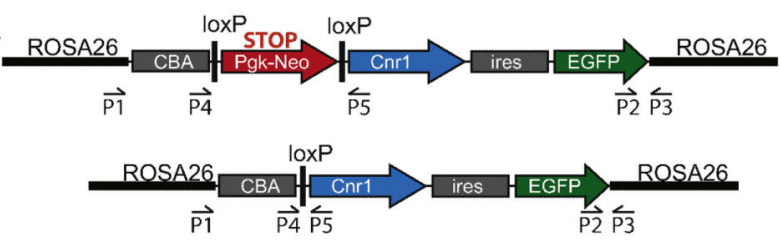

B

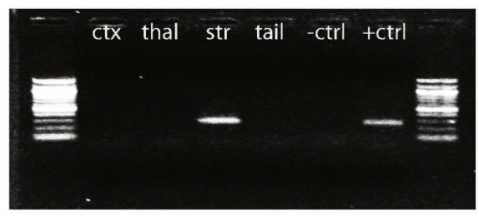

C
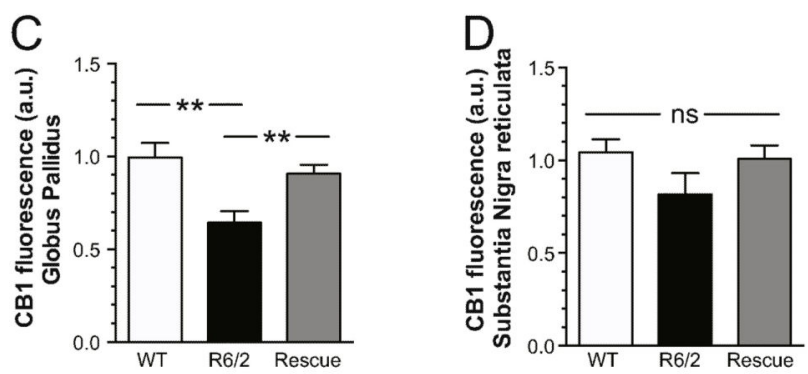
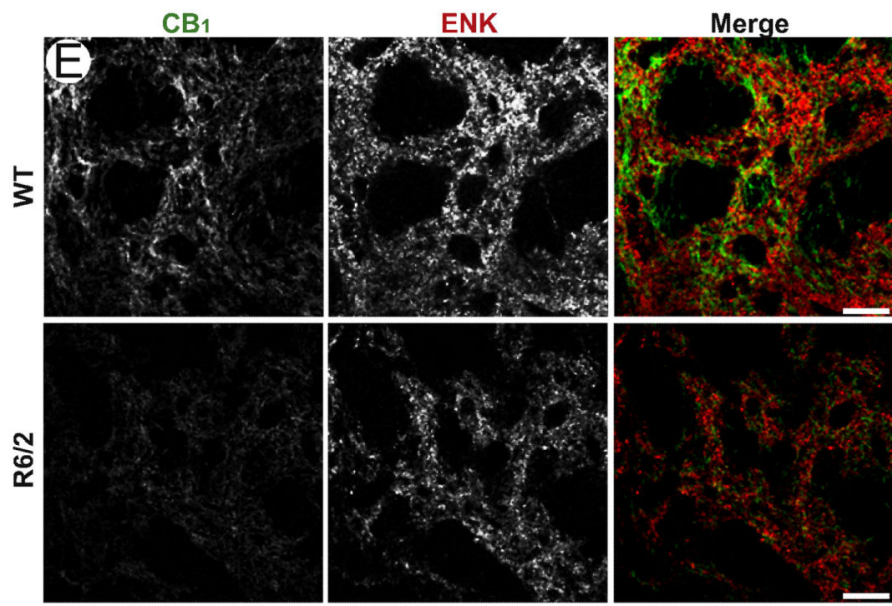

Figure 1. Knock-in and expression of $R_{2} \sigma^{f_{s} C B 1}$ restores $\mathrm{CB}_{1}$ (MSN) receptor expression in $\mathrm{R} 6 / 2$ mice
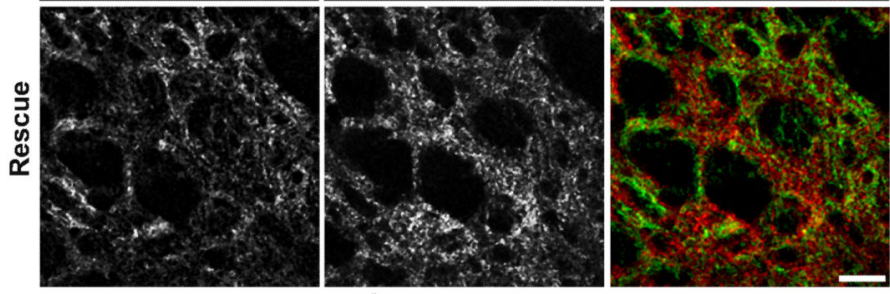

Globus Pallidus

(A) $\mathrm{An} \mathrm{fsCB}_{1}$ insert was generated and targeted to Rosa26, carrying Cnrl-ires-EGFP under a $C B A$ promoter with a flox-stop containing $P g k$-neo. (B) Tissue punches of cortex, thalamus and striatum were dissected on a freezing microtome and processed for DNA extraction. PCR was performed with primers flanking the pgk-neo sequence, such that the presence of a band would indicate that Pgk-neo has been removed and the insert has been activated. Pgk-neo excision by Cre was specific for striatal tissue, and was not observed in tail, cortex or thalamus. (C, D) Semi-quantitative IHC was used to verify that R6/2$\mathrm{CB}_{1(\mathrm{MSN})}$ rescue ( $\left.\mathrm{n}=8\right)$ resulted in restoration of $\mathrm{CB}_{1}$ protein to $\mathrm{WT}(\mathrm{n}=14)$ levels in the GP and $\mathrm{SNr}$. (C) Whereas 12-week $\mathrm{R} 6 / 2$ mice $(\mathrm{n}=11)$ exhibit significant loss of $\mathrm{CB}_{1}$ protein from the GP, R6/2-CB 1 (MSN) rescue mice expressed WT-levels of $\mathrm{CB}_{1}$ receptors. (D) Notably, $\mathrm{CB}_{1}$ protein loss is not observed in the $\mathrm{SNr}$ in 12-week $\mathrm{R} 6 / 2$ mice. (E) Representative images are shown from the GP of R6/2, WT, and R6/2-CB $1(\mathrm{MSN})$ rescue mice. Images were acquired on a Leica confocal, using an oil-immersion $63 \times$ objective. Scale bars indicate $25 \mu \mathrm{m}$. All error bars indicate S.E.M. and post-hoc analyses were carried out with Fisher's $\mathrm{T}$ test as indicated by $* p<.05, * * p<.01$. 
A

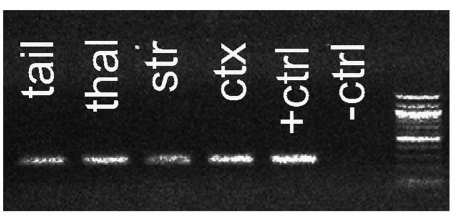

B

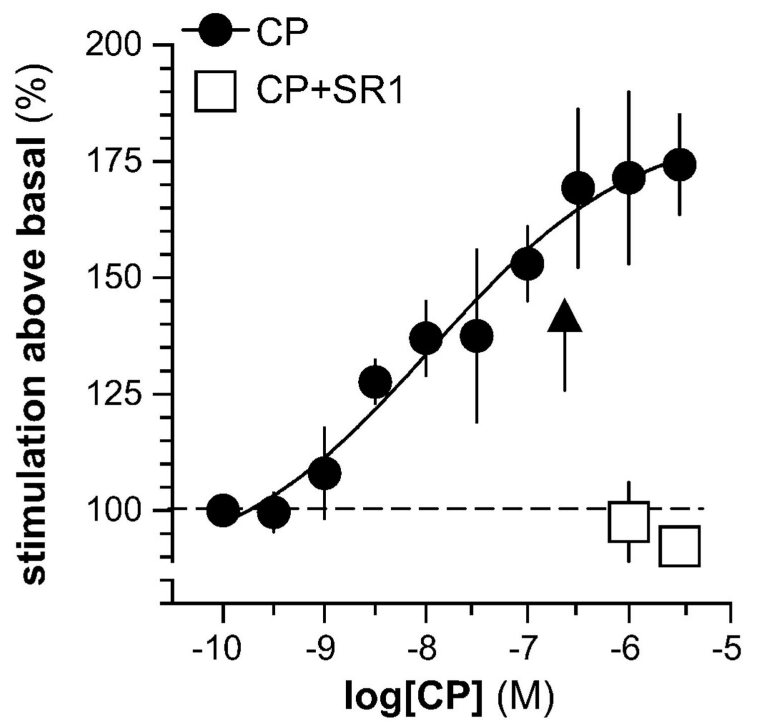

C

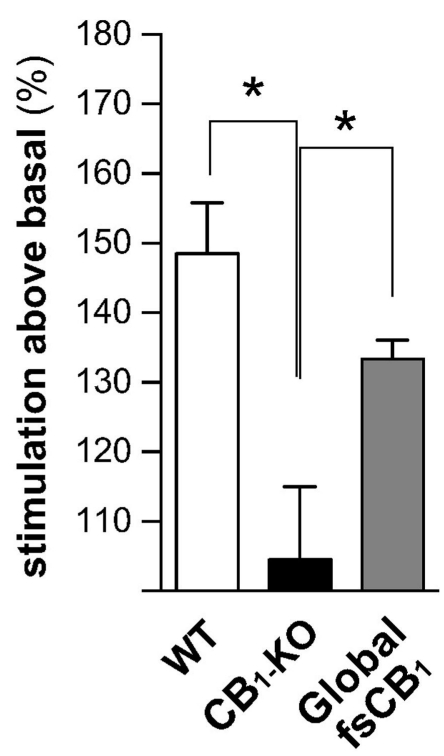

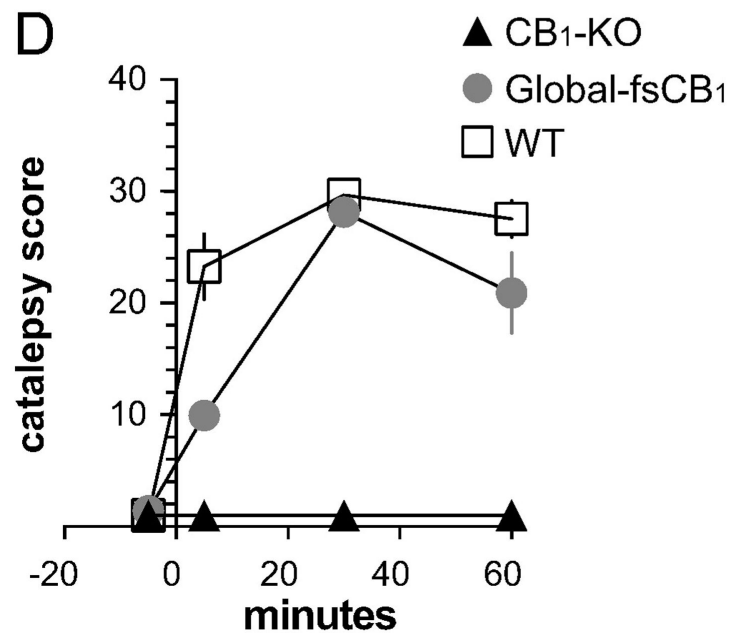

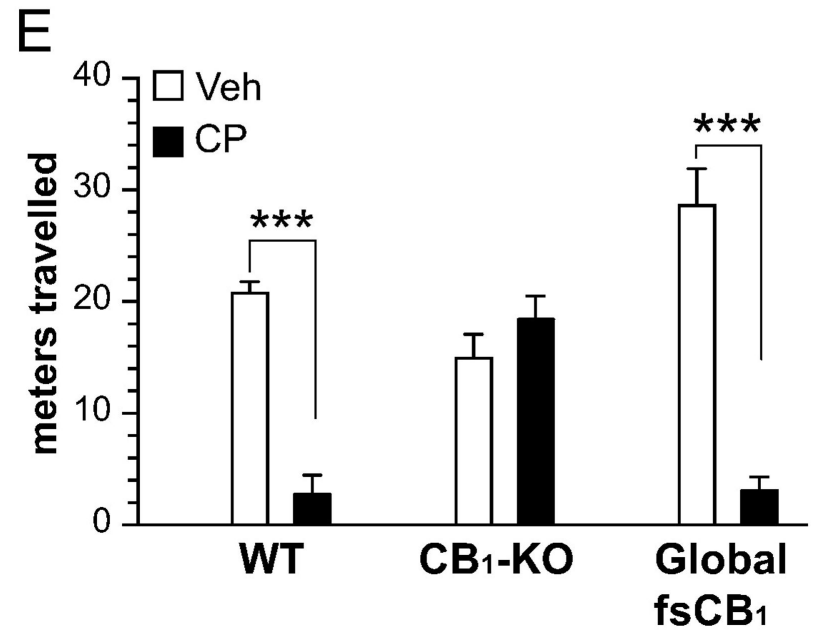

Figure 2. Receptors expressed from the $R 26^{\mathrm{fsCB} 1}$ locus are functional

To test the functionality of $\mathrm{fsCB}_{1}$-derived protein, we crossed $\mathrm{Cnr1^{-/ }}$ Gpr88 ${ }^{+/ C r e}$ females with $C n r 1^{-/-} R 26^{+/ f s C B 1}$ males, since Gpr88 is expressed transiently in the ova resulting in global excision of $P g k-N e o$. Thus, the resulting mice had no endogenous $\mathrm{CB}_{1}$ protein, but expressed $\mathrm{fsCB}_{1}$-derived $\mathrm{CB}_{1}$ protein in all tissues (global-fsCB $\mathrm{CB}_{1}$ mice). (A) PCR demonstrating $P g k$-Neo excision in brain and peripheral tissue. (B) Using pooled $\mathrm{SNr}$ tissue from 4 WT mice, a dose response curve was established for CP55,940. (C) In harvested SNr tissue, GTP $\gamma \mathrm{S}$ binding was induced by an $\mathrm{EC}_{80}$ dose of $140 \mathrm{nM} \mathrm{CP55,940}$ in WT $(\mathrm{n}=4)$ and Global-fsCB 1 mice ( $\mathrm{n}=5)$, but not in $\mathrm{Cnrl}^{-/-}$mice (n=4). (D) After treatment with 0.3 $\mathrm{mg} / \mathrm{kg}$ CP55,940, we measured catalepsy in WT $(\mathrm{n}=6), \mathrm{Cnrl}^{-1-}(\mathrm{n}=7)$, and Global-fsCB 1 mice ( $\mathrm{n}=7$ ). The cataleptic response observed in WT mice was absent in $\mathrm{Cnrl}^{-/}$mice, and restored in Global fsCB 1 mice. (E) Similarly, CP55,940 induced hypolocomotion in WT mice, which was lost in $\mathrm{Cnrl}^{-1-}$ mice, and restored in global-fsCB $\mathrm{f}_{1}$ mice. Post-hoc 
comparisons were performed with Fisher's T-test, with $* p<.05, * * p<.01, * * * p<.001$. Error bars depict S.E.M. 
A
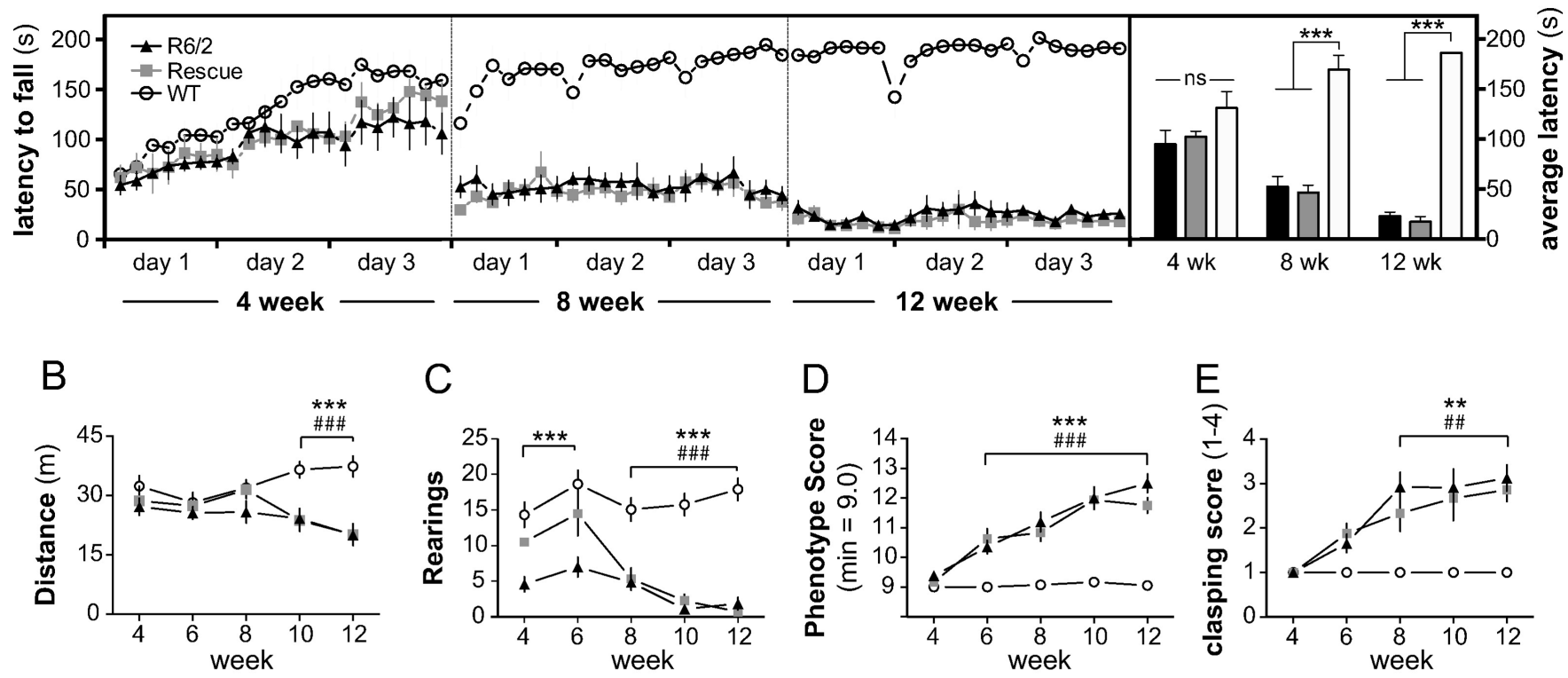

F

R6/2 $\square$ Resc $\square$ WT

G

$\mathrm{H}$
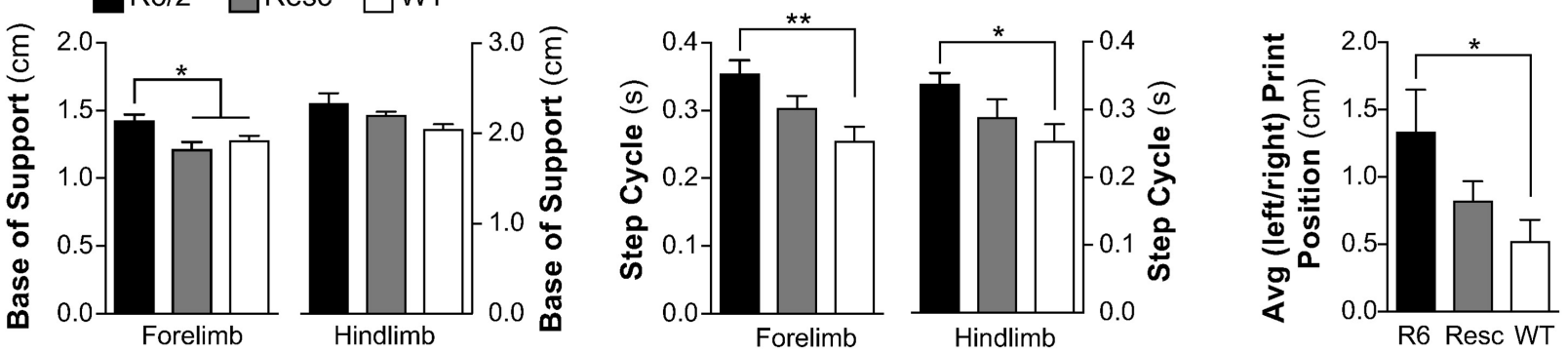

I

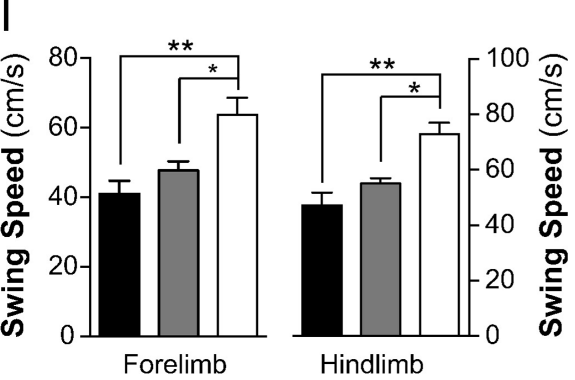

$\mathrm{J}$
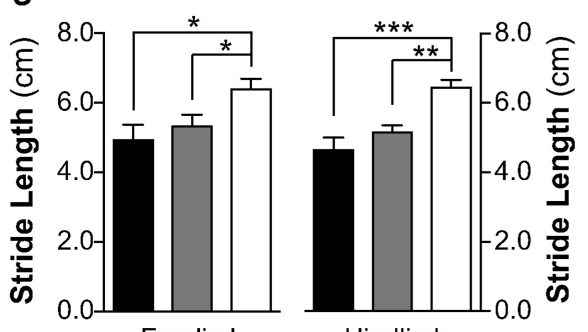

$\mathrm{K}$

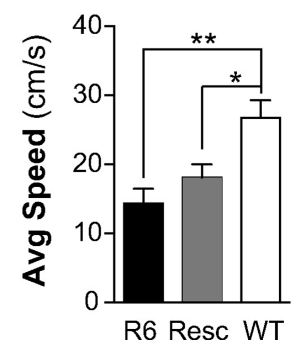

Figure 3. The rescue of functional $\mathrm{CB}_{1}(\mathrm{MSN})$ receptors does not rescue the $\mathrm{R6} / 2$ motor phenotype

For all graphs, R6/2 mice are shown in black, R6/2-CB $1(\mathrm{MSN})$ rescue mice are shown in grey, and WT mice are shown in white. (A) Rotarod performance was measured at 4, 8, and $12 \mathrm{wk}$, reflecting presymptomatic, early, and late symptomatic stages ( $\mathrm{n}=4-6$, all groups).

(B) In an open field chamber, locomotion was scored using Noldus Ethovision software, and rearing $(\mathrm{C})$ was manually recorded over the first two $\min (\mathrm{WT}, \mathrm{n}=15$; R6/2, n=13; R6/2$\mathrm{CB}_{1(\mathrm{MSN})}$, $\mathrm{n}=8$ ). (D) Manual scoring of the R6/2 motor phenotype along 9 measures (see methods), and clasping behavior (E). Gait analysis was performed at $10 \mathrm{wk}$ of age, and base of support $(\mathrm{F})$, step cycle $(\mathrm{G})$, print position $(\mathrm{H})$, swing speed (I), stride length $(\mathrm{J})$, and 
average speed $(\mathrm{K})$ were measured in Noldus Ethovision. Error bars indicate S.E.M., and Fisher's T test was used for post-hoc analyses with $* p<0.05$, $* * p<0.01$, and $* * * p<0.001$. For (B-E). Comparison between WT and R6/2 mice denoted by *; WT and R6/2-CB ${ }_{1(\mathrm{MSN})}$ mice denoted by $\#$. 

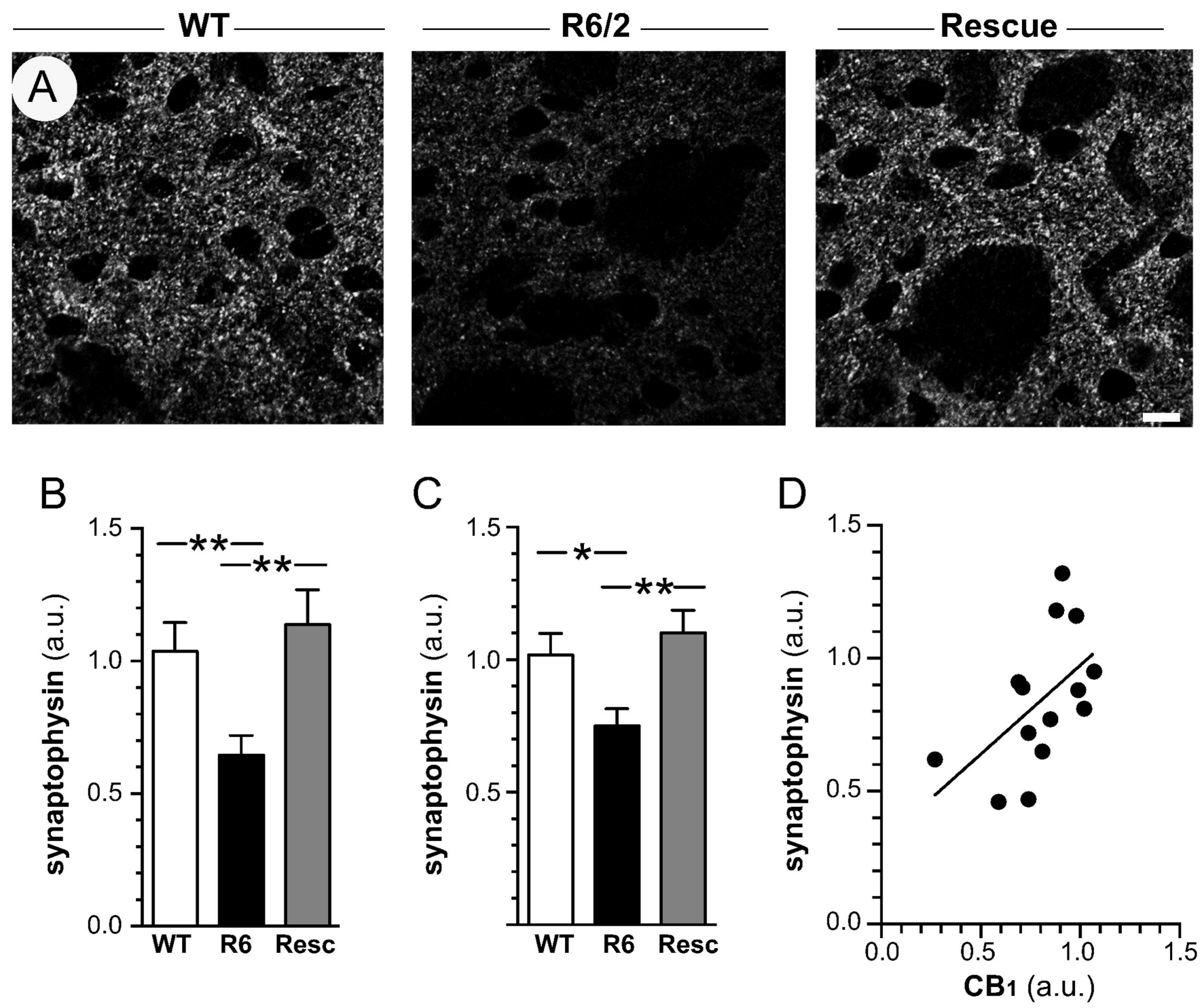

Figure 4. Loss of striatal synaptophysin in $\mathrm{R} 6 / 2$ mice is rescued by genetic restoration of CB 1 (MSN) receptors

(A) Representative images of dorsal medial striatal synaptophysin staining in sections from 12 week old mice are shown with background subtraction. R6/2 ( $\mathrm{n}=10)$ sections showed both a decrease in overall intensity and fewer hyperintense foci in both dorsal-medial (B) and dorsal-lateral striatum $(C)$, which was restored to WT $(n=14)$ levels in $R 6 / 2-C_{1}(M S N)$ mice $(n=7)$. (D) Within-subject plots of striatal synaptophysin staining against $\mathrm{CB}_{1}$ receptor staining in the GP show a positive linear correlation between $\mathrm{CB}_{1}$ receptors and synaptophysin intensities in 12-wk-old mice ( $\mathrm{n}=17, \mathrm{R} 6 / 2$ and $\mathrm{R} 6 / 2-\mathrm{CB}_{1(\mathrm{MSN})}$ groups pooled). Error bars depict S.E.M., and Fisher's T-Test was used for post-hoc analyses, with $* p<.05$, and $* * p<.01$. Scale bar $=10 \mu \mathrm{m}$. 

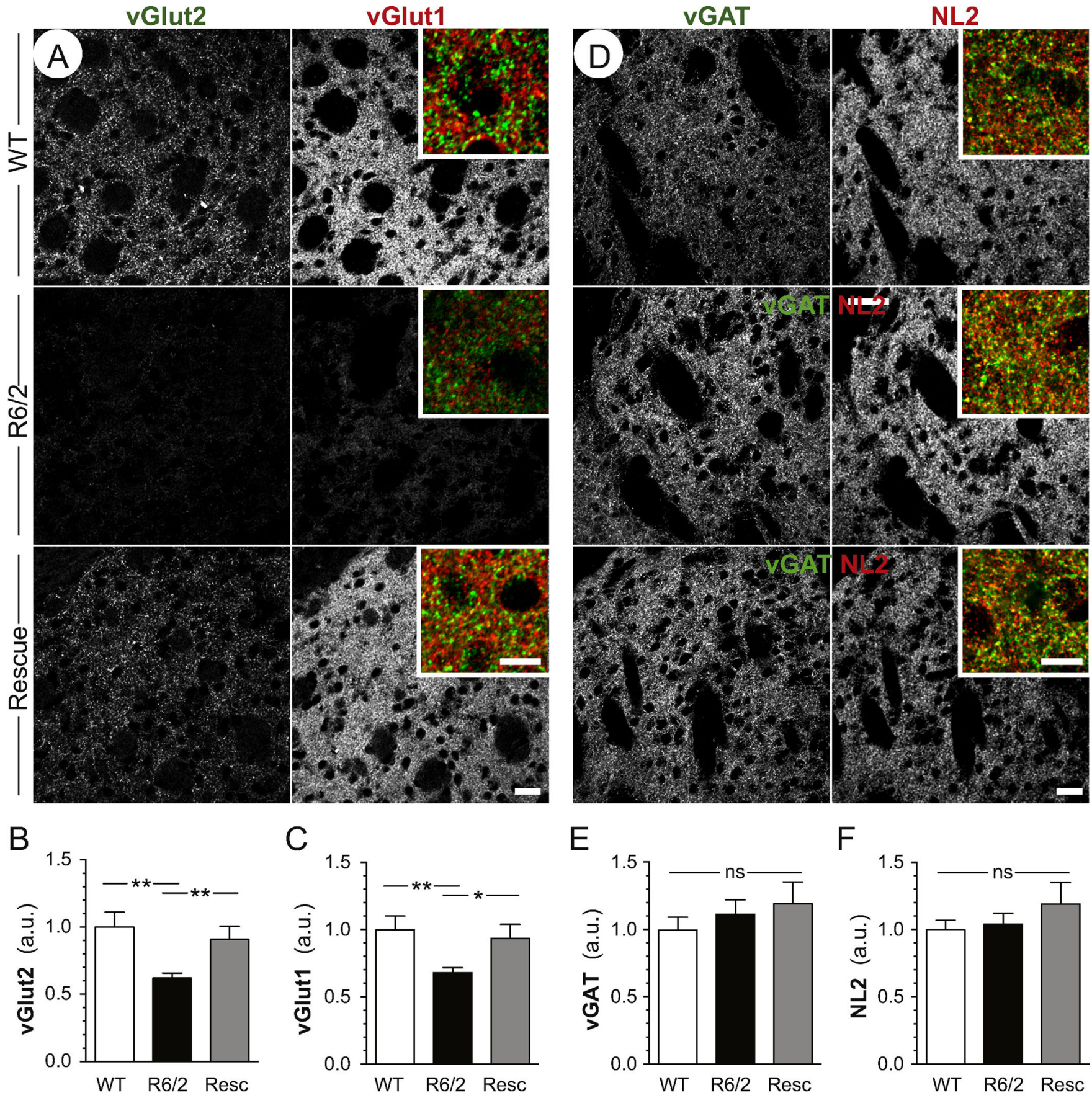

Figure 5. R6/2-CB 1 (MSN) mice do not lose excitatory striatal synapses

To determine the specificity of synaptic loss, we co-stained slices from 12 week old mice for vGLUT1 and vGLUT2 (A-B, representative images, scale bar $=25 \mu \mathrm{m}$ ) or vGAT and NL2 $(\mathrm{C}-\mathrm{D}$, representative images, scale bar $=25 \mu \mathrm{m})$. There was a reduction in staining of both vGLUT2 (E) and vGLUT1 (F) in R6/2 mice ( $\mathrm{n}=12$ ) compared with WT (n=9), which did not occur in $\mathrm{R} 6 / 2-\mathrm{CB}_{1(\mathrm{MSN})}$ mice $(\mathrm{n}=7)$. No reduction in either vGAT or NL2 immunostaining was detected in either $\mathrm{R} 6 / 2$ or $\mathrm{R} 6 / 2-\mathrm{CB}_{1(\mathrm{MSN})}$ mice $(\mathrm{G}-\mathrm{H})$. All images were acquired with a Leica confocal microscope and are presented with the same settings. Insets represent a $4 \times$ 
digital zoom, with vGLUT2 in green and vGLUT1 in red (B) or with vGAT in green and NL2 in red (D). Scale bars depict $25 \mu \mathrm{m}$ and $10 \mu \mathrm{m}$ (insets), and error bars show S.E.M. Post-hoc analyses were performed with Fisher's T Test, and are indicated by $* p<.05$, ** $p<$. 01 . 

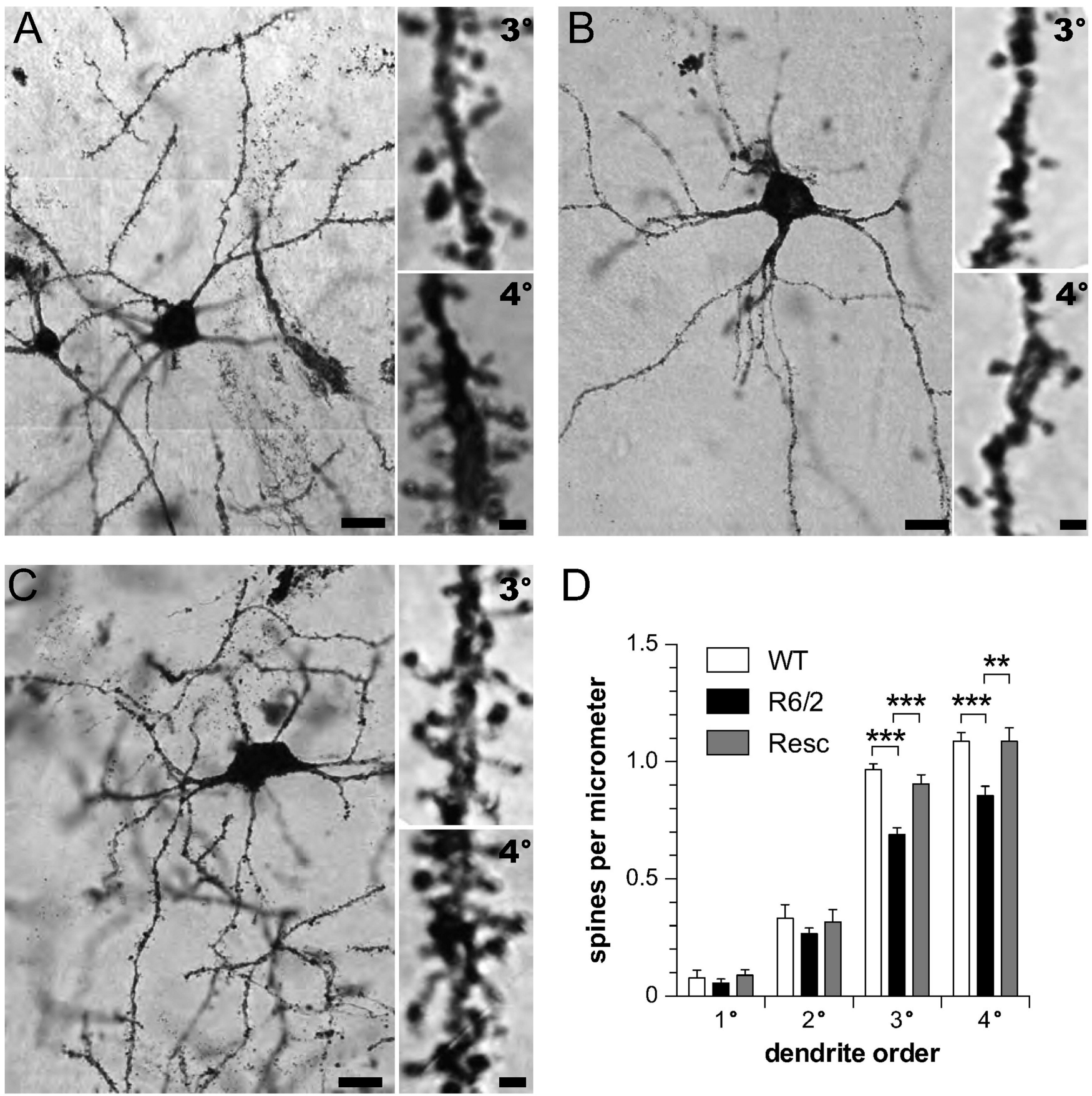

Figure 6. Dendritic spine loss in $\mathrm{R} 6 / 2$ mice is rescued in $\mathrm{R} 6 / 2-\mathrm{CB}_{1}(\mathrm{MSN})$ mice

We performed on-slice Golgi staining and quantified dendritic spines on up to four orders of dendrites on MSNs from 12 week old mice. Extended focus montage images of single MSNs or both $3^{\text {rd }}$ and $4^{\text {th }}$ order dendrites (insets) are presented for WT (A), R6/2 (B) and R6/2-CB 1 (MSN) (C) mice. (D) Density of dendritic spines from $n=9$ MSNs (from 3 mice per group) were manually counted from z-stack montage images in ImageJ. Scale bars depict 10 $\mu \mathrm{m}$ and $1 \mu \mathrm{m}$ in main images and insets, respectively. Error bars show S.E.M. Post-hoc 
analyses were performed with Fisher's T Test, and are indicated by ${ }^{*} p<.05, * * p<.01$, $* * * p<.001$. 

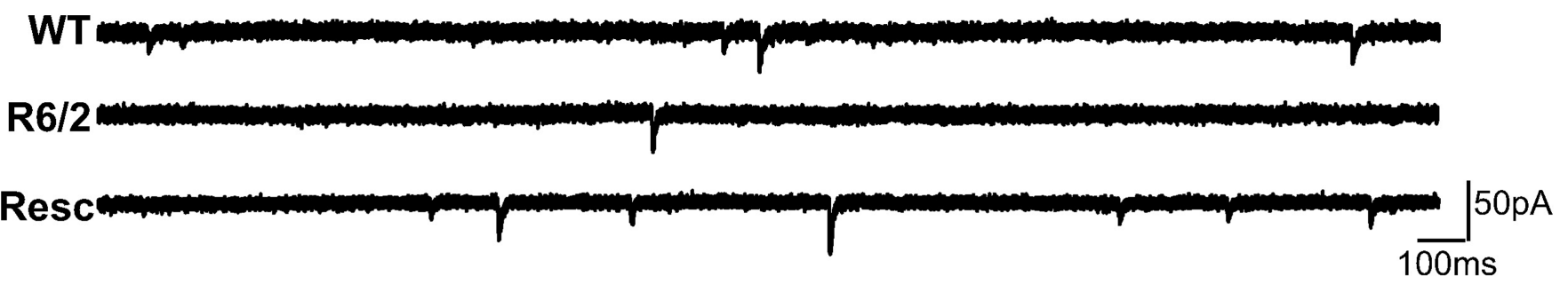

A

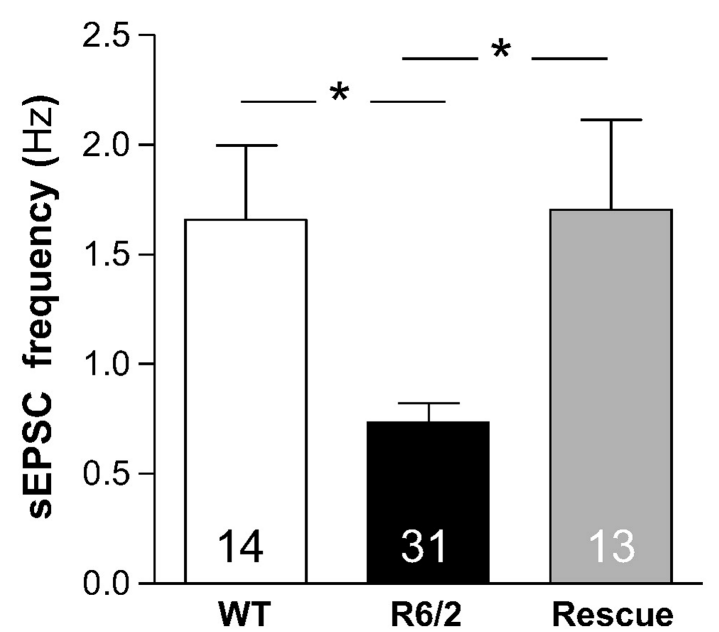

B

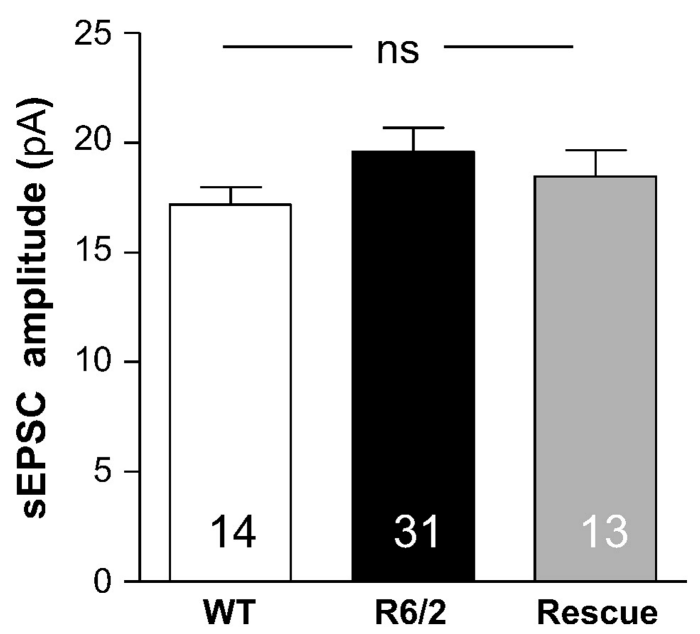

Figure 7. Functional excitatory synapses are rescued in $\mathbf{R 6} / \mathbf{2}-\mathrm{CB}_{1}$ (MSN)

Representative traces of spontaneous excitatory post-synaptic currents (sEPSC) and summary group data show (A) reduction in sEPSC frequency in 12-week old R6/2 (number of cells indicated within bar, from $n=9$ mice) compared to WT (from $n=6$ mice). $s E P S C$ frequency in $\mathrm{R} 6 / 2-\mathrm{CB}_{1(\mathrm{MSN})}$ (from $\mathrm{n}=4$ mice) is greater than in $\mathrm{R} 6 / 2$ mice and identical to sEPSC frequency in WT mice. (B) sEPSC amplitude shows no difference between genotypes. ${ }^{*} p<0.05$ one-way ANOVA with Bonferroni post-hoc. 
A
B

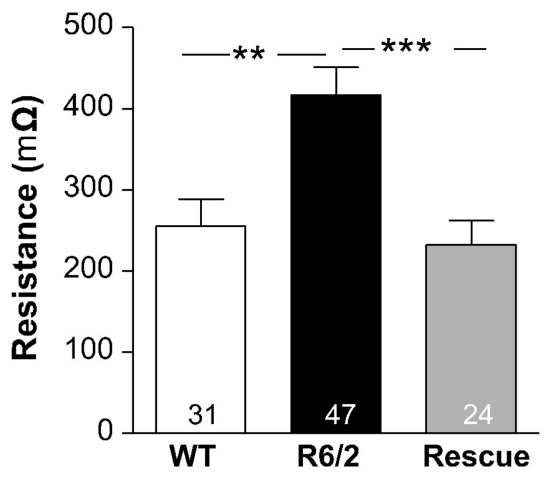

C

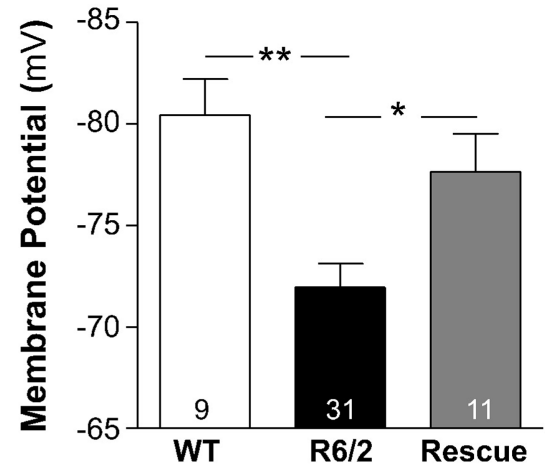

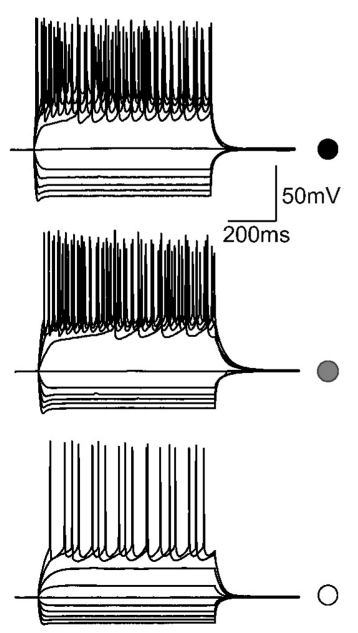

D

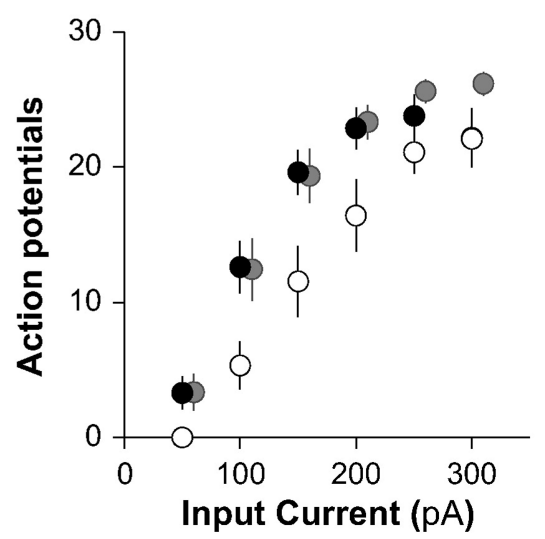

$E$

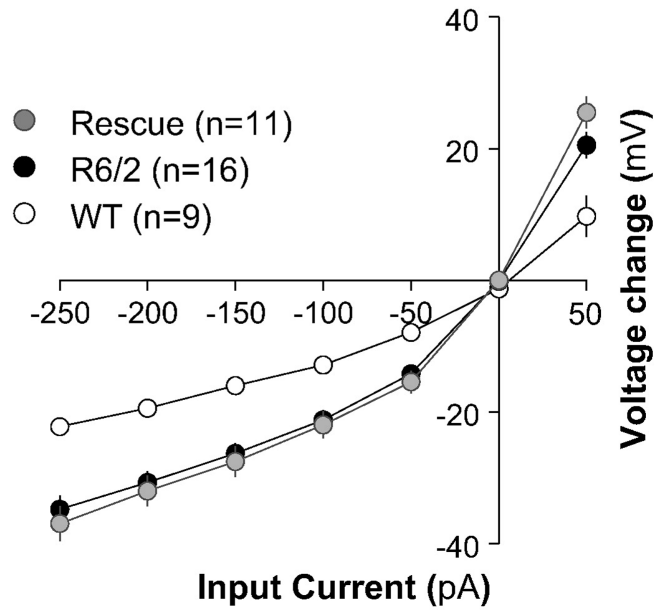

Figure 8. Intrinsic properties of $\mathrm{MSN}$ with genetic restoration of $\mathrm{CB}_{1}$ receptors

(A) At 12 weeks of age, whole-cell capacitance in MSNs of R6/2 mice (black bar, number of cells indicated within bar, from $n=9$ mice) was significantly reduced compared with WT mice (white bar, from $n=6$ mice) and restored in $\mathrm{R} 6 / 2-\mathrm{CB}_{1(\mathrm{MSN})}$ mice (grey bar, from $\mathrm{n}=5$ mice). Data was (B) Membrane resistance measured in R6/2 MSN is significantly higher than in WT MSNs, but membrane resistance in $\mathrm{R}_{6} / 2-\mathrm{CB}_{1(\mathrm{MSN})}$ mice is WT levels. (C) Resting membrane potential of MSN is more depolarised in R6/2 mice compared with WT and R6/2-CB 1 (MSN) mice. (D) Summary of current-firing curves indicating that the number of evoked action potentials in response to somatic current steps in MSNs of R6/2 and R6/2$\mathrm{CB}_{1(\mathrm{MSN})}$ mice are significantly different than WT mice. Typical membrane responses to somatic current steps of dorsal striatal MSNs from WT (open circle), R6/2-CB 1 (MSN) $($ grey circle) or R6/2 (black circle) mice are shown to the left. (E) Summary current-voltage (I-V) curves from somatic current steps show a difference between WT and both R6/2 and R6/2$\mathrm{CB}_{1(\mathrm{MSN})}$ mice. (A-C) $* p<0.05$, ** $p<0.01$, *** $p<0.001$ by Bonferroni post-hoc from one-way ANOVA (D,E) Two-way ANOVA for repeated measures with Bonferroni posthoc. Comparison between WT and R6/2 mice denoted by * ; WT and R6/2-CB $1(\mathrm{MSN})$ mice denoted by ${ }^{\#}$. 